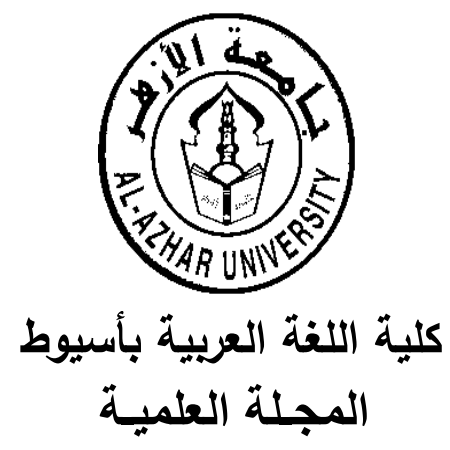

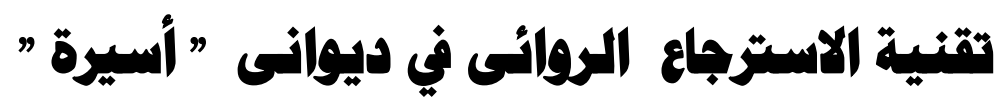

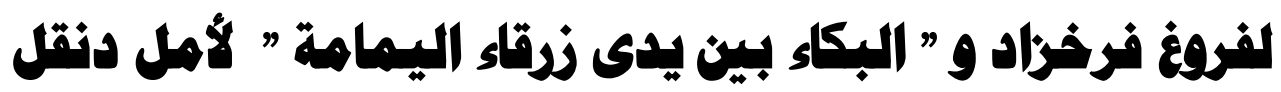
( دراسة مقارنة )

\author{
| - اعداد \\ د ماشم محمد هاشم \\ مدرس اللغة الفارسية وآدابها \\ بقسم اللغات الثرقية، كلية الآداب جامعة أسيوط \\ ( العدد الأربهمون )

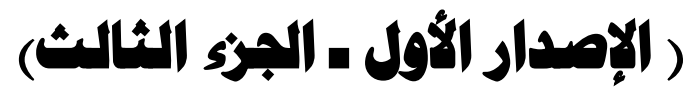 \\ ( $A R+r) / A \mid\{\varepsilon r)$
}


تقنية الاسترجاع الروائى في ديوانى ” أسيرة ” لفروغ فرخراد و " البكاء بين يدى زرقاء اليسمامة ” لأهل دنقل (دراسة هقارنة) هاشم محمد هاشم. قسم اللغة الفارسية وآدابها، قسم اللفات الثرقية، كلية الآداب، جامعة أسيوط، مصر hashemelkomey@ art.aun.edu.eg البريد الإكتروني: المانص: منذ مطلع القرن العشرين تداخلت الأجناس الأدبية، واستعار كل جنس أدبي تقنيات الأجناس الآخرى بما يخدم النص ومضمونه وروئية المبدع، وكان الثـعر مـن أكثر الأجنـاس الأدبيـة استعارة لتقتيـات الأجنـاس الأخرى، خاصـة تقتبـات الرواية، وتركز هذه الدراسـة على إبراز استعارة الثـعر الفارسي والعربي الحديث لأحدى تقتيـات الزمن الروائسى، ألا وهـى تقتيـة "الاسترجاع الروائسى"، وذلكك مـن خلال ديوانى: "أسيرة" للشـاعرة "فروغ فرخزاد" و"البكاء بين يدى زرقاء الدهـ اليمامـة" للشاعر "أمل نقل". وتهدف هذه الدراسة إلى الكشف عن أسباب وطرق توظيف تقنية الاسترجاع الروائى عند كل من الثاعرة (فروغ فرخزاد) في ديوانها: "أسيرة" والثاعر" أمل دنقل" في ديوانه: "البكاء بين يدى زرقاء اليمامة". وتعتمد الدراسة على المنهج المقارن وفقا لمباديء المدرسـة الأمريكيـة، كمـا تستعين الدراسـة بالمنــاهج الأخـرى مثـل : المـنهج النقـــي، والتحليلي، والبنيـوى، للوصـول إلـي

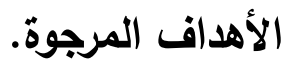




\section{الكلمات المفتاهية:}

المفارقة الزمنية، تعريف الاسترجاع الروائى وأنواعه، الاسترجاع الروائى في

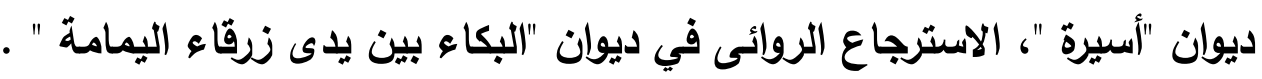




\section{Narrative Flashback Technique}

\section{In the Poetry Collections " Asirah" by Forugh} Farrokhzad and "Al-Buka' Bayn Yaday Zarqa"

\section{Al-Yamamah" by Amal Donqol}

\section{(A Comparative Study)}

Hashem Mohammed Hashem.

Department of Persian Language and Literature, Department of Oriental Languages, Faculty of Arts, Assiut University, Egypt.

E-mail: hashemelkomey@ art.aun.edu.eg

Abstract: Since the beginning of the twentieth century, literary genres have overlapped, and each genre borrowed the techniques of the others, which worked in favor of the text, its content and the vision of the writer. Poetry was one of the most literary genres to borrow techniques from the other genres, especially the narrative techniques. This study focuses on illuminating the borrowing of narrative techniques by Persian and Modern Arabic Poetry: the borrowing of the flashback technique through the poetry collections "Asirah" by Forugh Farrokhzadand and "Al- Buka' Bayn Yaday Zarqa' Al-Yamamah " by Amal Donqol. The study aims to reveal the reasons and methods of employing the flashback technique by both poets, Forugh Farrokhzadand in her poerty collection "Asirah" and "Al- Buka' Bayn Yaday Zarqa' Al-Yamamah " by Amal Donqol. This study depends 
on the Comparative Theory according to the principles of the American School. The study also applies other methods such as the critical, analytical, and structural approach to achieve its intended purposes.

Keywords: He chronological paradox, The definition of narrative flashback and its kinds, Narrative flashback in the poetry collection "Asirah", Narrative flashback in the poetry collection "Al-Buka' Bayn Yaday Zarqa' AlYamamah 


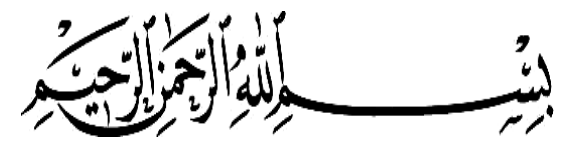

\section{intén}

مع بداية القرن العشرين حلث تغيير جذري في الأدب المعاصر ونقلة هائلة

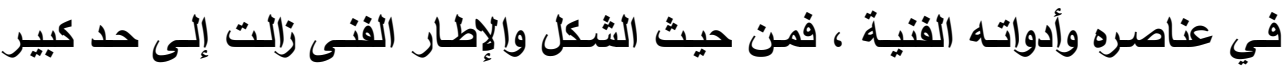

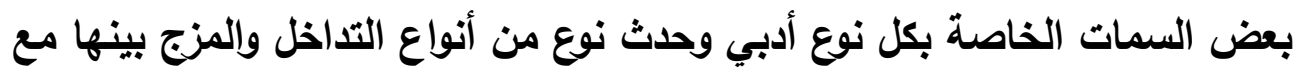

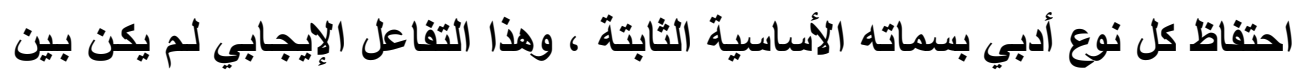

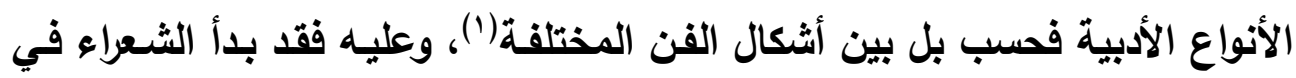

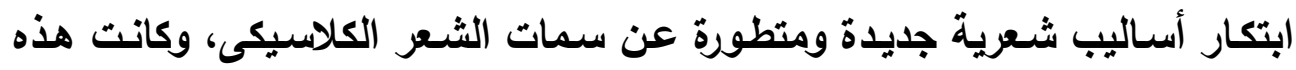
الأساليب المبتكرة تتوافق مـع روح العصر وتتزامن مـع تطور الثـعر، وفي وفي المقابل

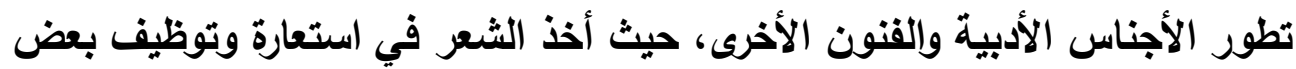

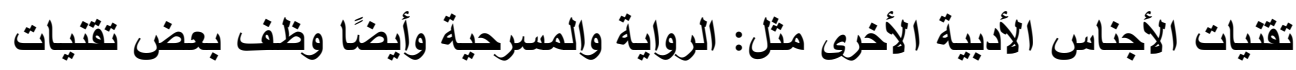

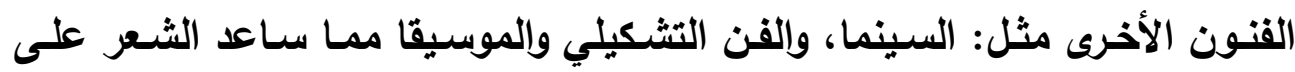

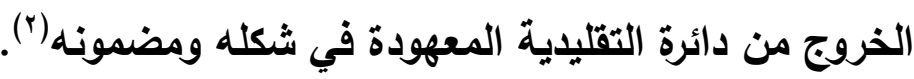
ومن صور تطور الشعر الفارسي والعربي لجوء الشعراء في قصائدهم إلى

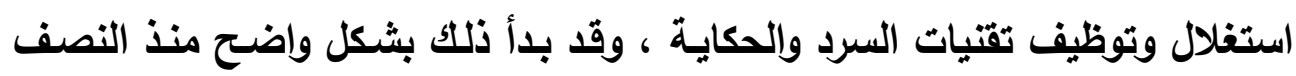

(1) طه وادي: جماليات القصيدة المعاصرة، الطبعة الأولى، الثركة المصرية العالمية للنشر-

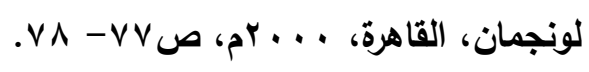

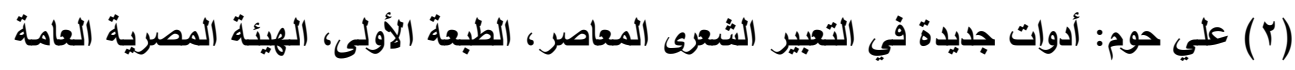

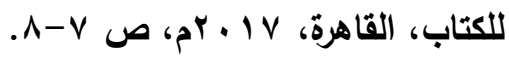


الثانى من القرن العشرين-تقريبًا- وذلك يتوافق مـع تطور تقتيات الرواية والقصـة

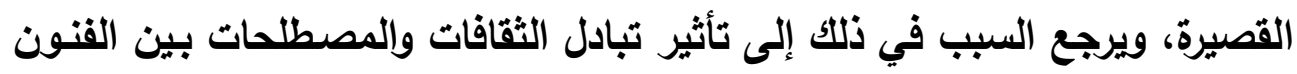

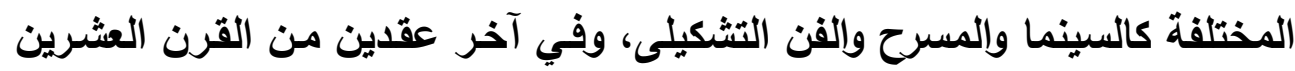

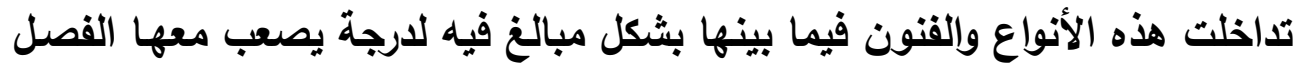

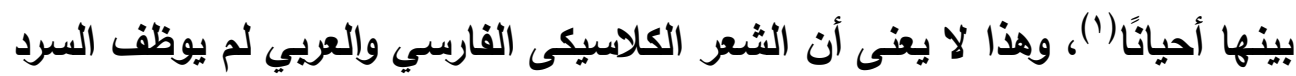

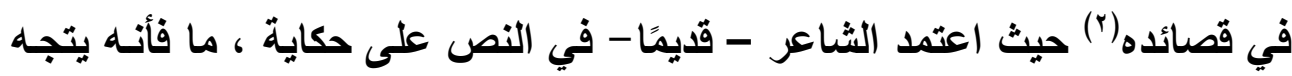

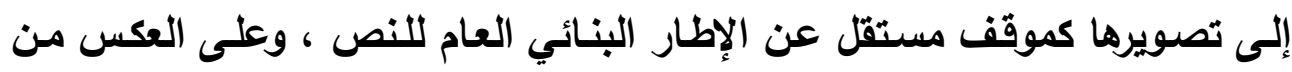

(1) محمد زيدان: البنيـة السردية في النص الثـعري، الطبعة الأولـى، الهيئة العامـة لقصور

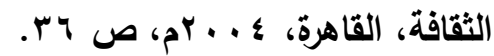

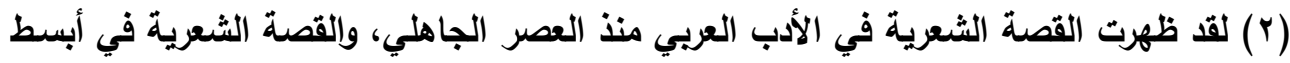

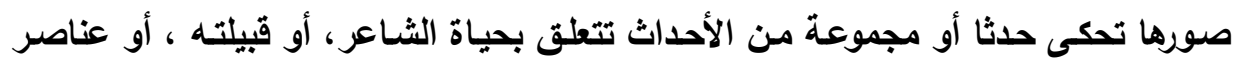

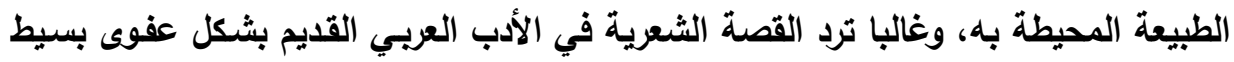

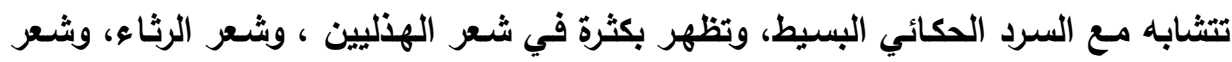

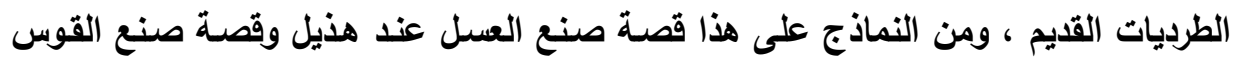
عند أوس بن حجر، وكذلك ظهرت القصة الشعرية في الشعر الفارسي بشكل كبير وأبيز مثال

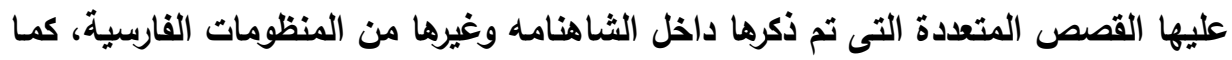

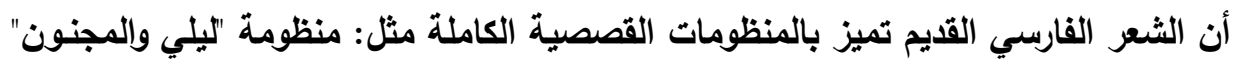

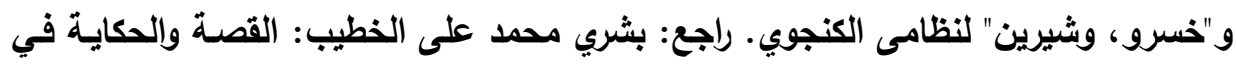

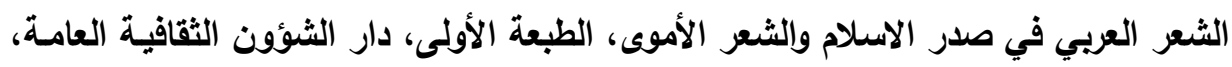

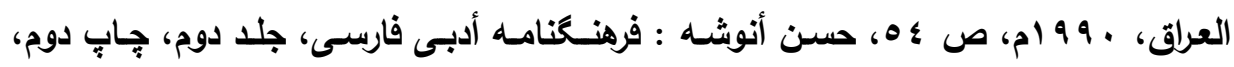

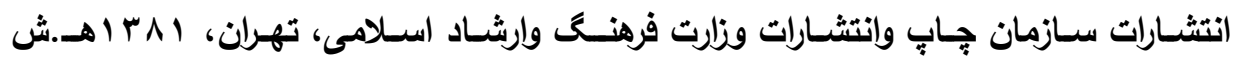

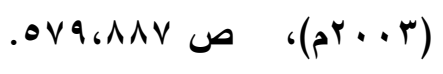


ذللك في الثعر الحديث حيث اعتمد الثعراء في تثكيل الثعر الحديث لبنية الخطاب السردي على المفهوم الحديث للسرد المستخدم في الرواية(1).

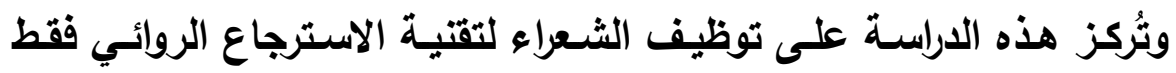
والتى تُعد من أهم تقنيات عنصر الزمن (ץ) في الرواية، حيث يُعد الزمن من العناصر

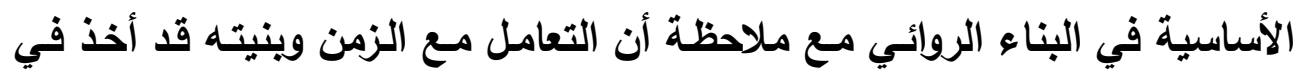
التحول والتغيير مع تطور فن الرواية ذاته، فهناك اختلاف بين استخدام الزمن في

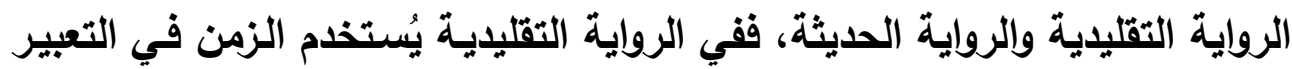
عن نمو الحدث وتطور الثخصيات بثكل خطى ثابت يشبه سيرة الحياة، أمسا في رواية القرن العثرين - الروايـة الحديثة- أخذ الزمن أو جمعًا مختلفة أكثر تقتية

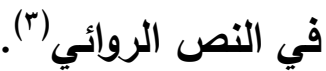

(1) محمد زيدان: البنية السردية في النص الثعري، مرجع سابق، ص أب.

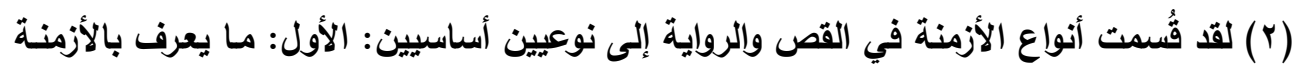

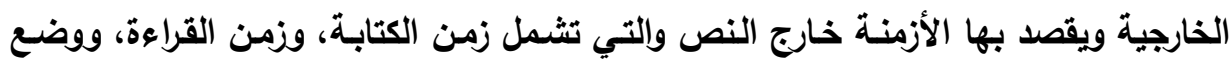

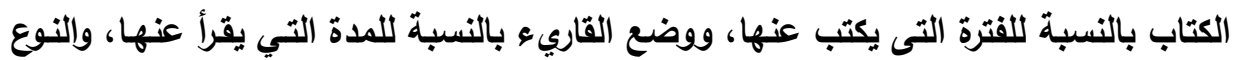

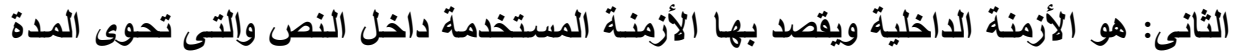

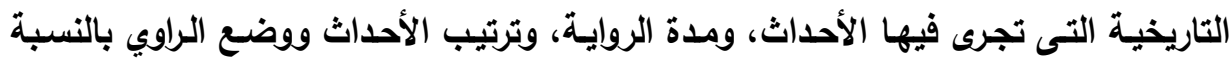

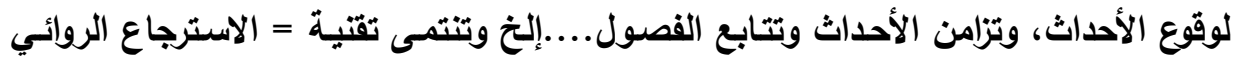

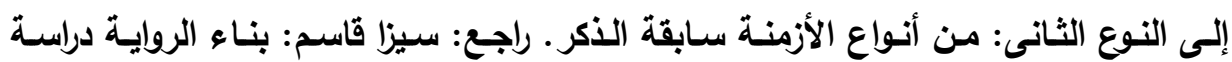
مقارنة في ثلاثية نجيب محفوظ، الطبعة الأولى، الهيئة المصرية العامـة للكتاب، القاهرة، الكاهية

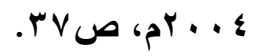
(T) أمينة رشيد: تثظى الزمن في الروايـة الحديثة، الطبعة الأولى، الهيئة المصرية العامـة

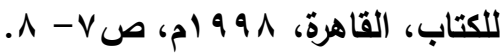


ويرى الباحث أن الثـعراء - سواء الفرس أو العرب - قد استظلوا هذه

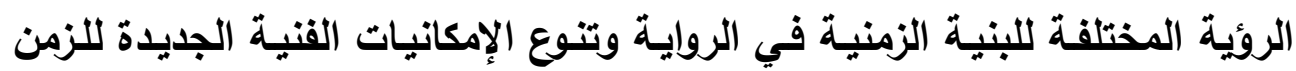
داخل النص الروائى ووظفوها في نصوصهم الثعرية بأشكال مختلفة حتى تساعدهم

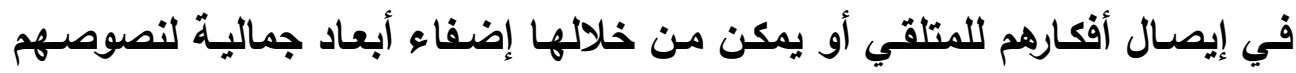

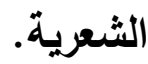

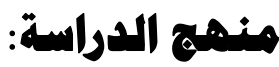

تعتمد الاراسة على المنهج المقارن وفقا لمباديء المدرسة الأمريكية، كما تستعين بالمناهج الأخرى مثل: المنهج النقدي، والتحليلي، والبنيوى، للوصول إلي

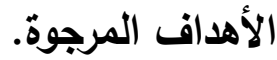

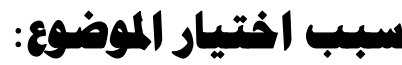

يرجع سبب اختيار هذا الموضوع إلى عدة أسباب من أهمها أن التداخل

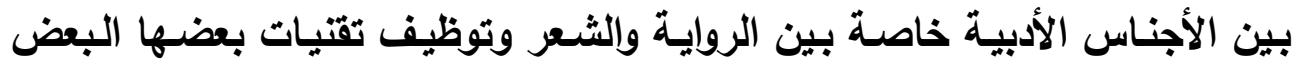

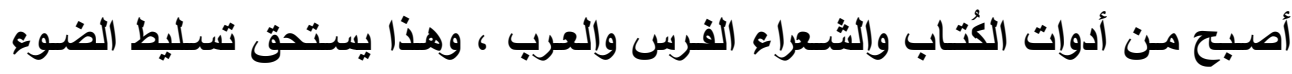

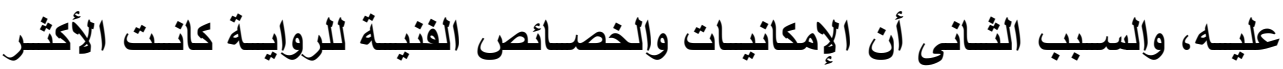
استخداما للدى الثـعراء مقارنـة بالاستفادة من عناصر وتقتيـات الأجناس الأدبيـة

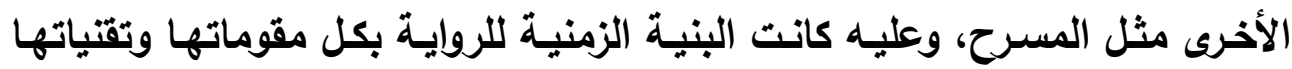
الأكثر توظيفـا للدى الثـعراء ؛ لأن الـزمن بالنسبة للثـعر عنصـر مـن عناصـره

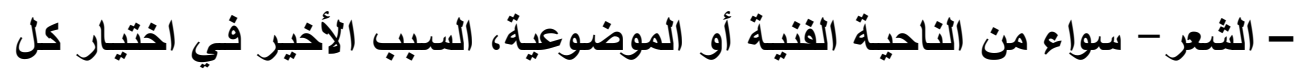

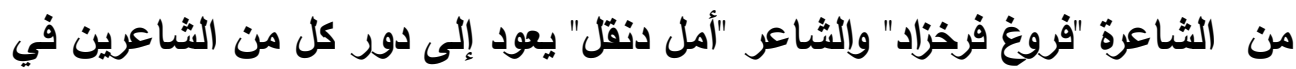

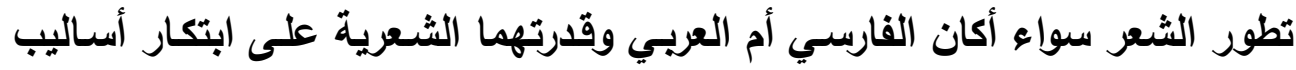
شعرية جعلت لشعر كل منهما طابعا خاصا مميزًا لهما. 
أما بالنسبة لاختيار وتحديد ديوان "أسيرة" للشـاعرة "فروغ فرخزاد" وديوان

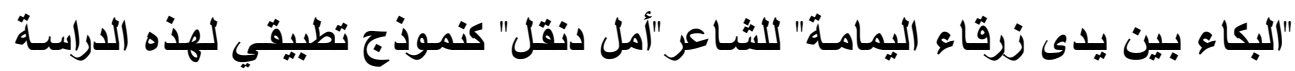

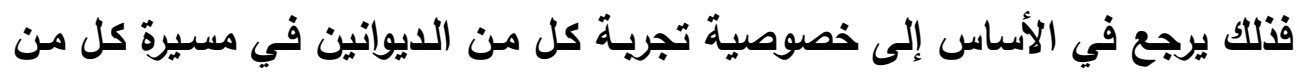

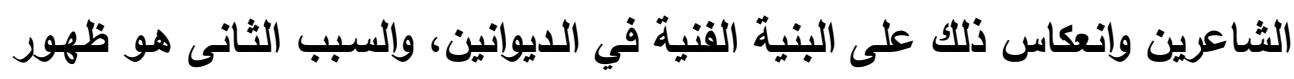

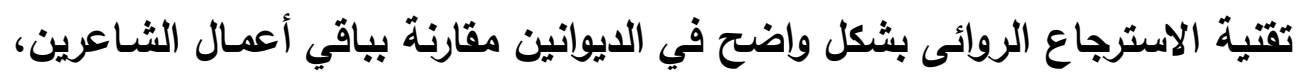

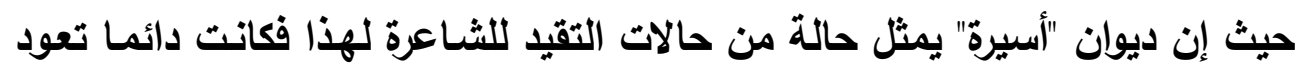

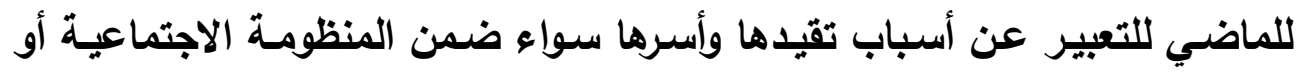

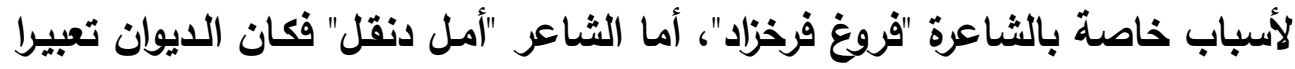
وتثريحا لمرحلة مـا بعد النكسة ؛ لهذا كانت استرجاعاته داخل النصوص توظيفا لتفسير أسباب الهزيمة والنكسة وإنعكاس ذلك على الثاعر والمجتمع بصفة عامة.

\section{أهداف الدراسة:}

تهاف هذه الاراسة إلى الكثف عن أسباب وطرق توظيف تقنية الاسترجاع

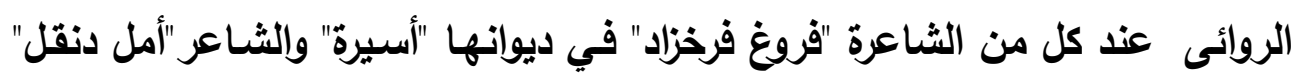
في ديوانه "البكاء بين يدى زرقاء اليمامة".

الدراسات السابقة:

لم يصل لعلم الباحث وجود دراسـة عربيـة أو فارسية تناولت المقارنـة بين

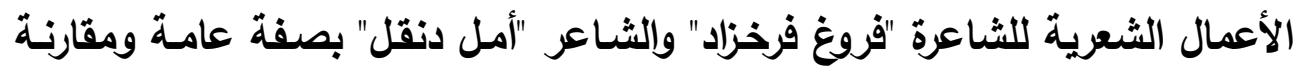

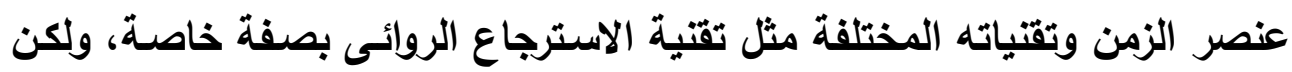

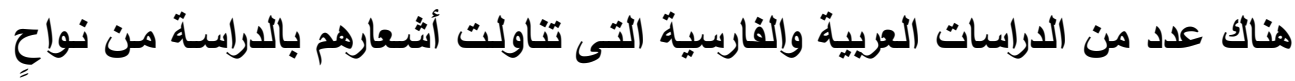

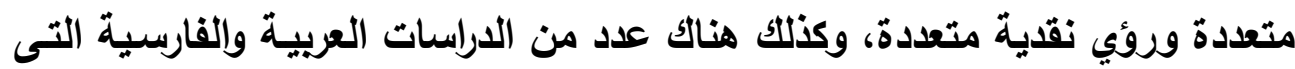

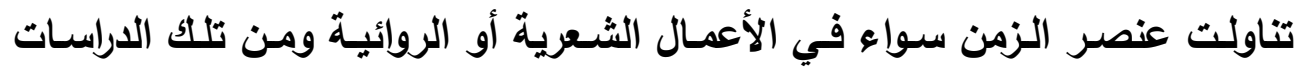
الآتى: - 20 - n 


\section{أ أ الدراسات العربية:}

1- رسول بلاوى وحسين طرفى عليوى: البنية الزمنية بين الاسترجاع والاستباق

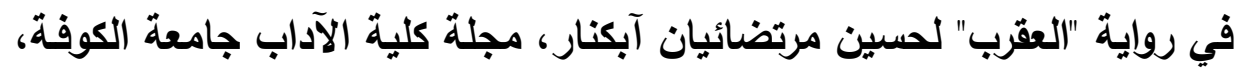

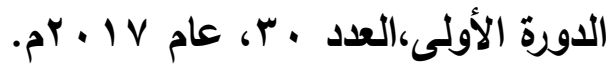

ץ- سعيد سوارى: دراسة توظيف التقتيات الزمانية فى روايـة "ذاكرة الجسد" لأحلام

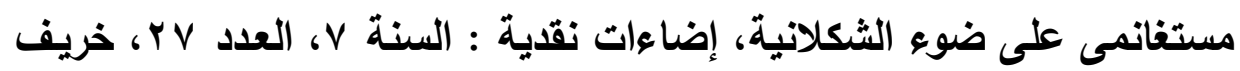

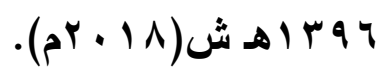

r- كبرى روشنفكر و فرشته آذرنيا: الزمن الروائى في رواية "رماد الثرق" لواسينى

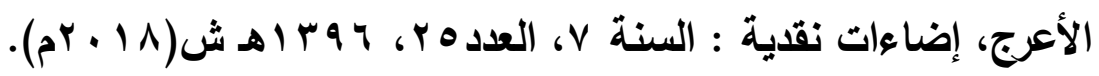

ب- الدراسات الفارسية:

1- ارسلان كلفام وديكران: استعاره اى زمان در شعر فروغ فرخزاد از ديدكاه زيـان

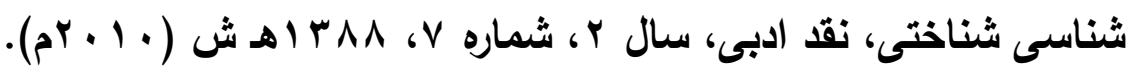
r- افسانه محمدى: بررسى مكان وزمان در رمان "مرافىء الحب السبعة" اثر على دانى

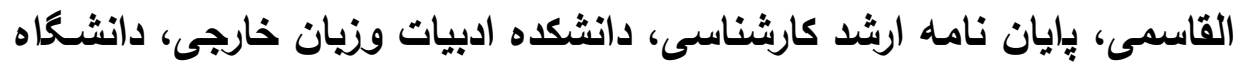

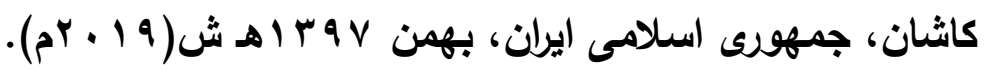
ץ- رضا ناظميان: زمان در شعر فروغ فرخزاد ونـازك الملائكة بررسى تطبيقى دو

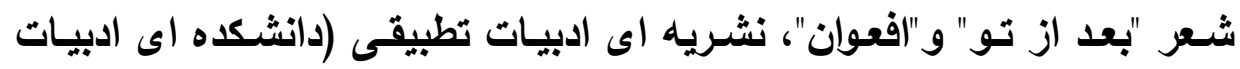

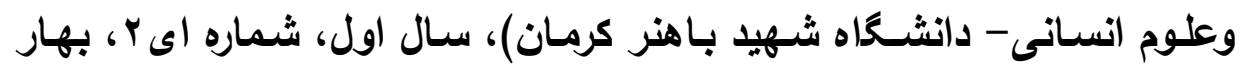

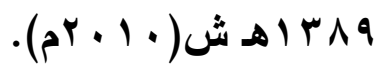


r- فروغ صهبا: بررسى زمـان در تـاريخ بيهقى بر اسـاس نظريـه اى "زمـان در

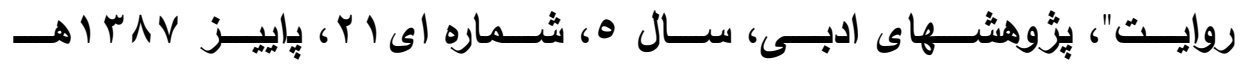

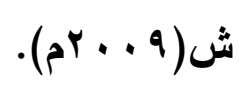

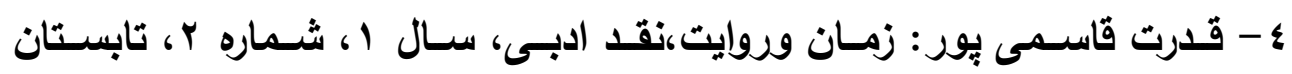

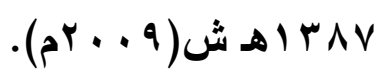

\section{عينة الدراسة:}

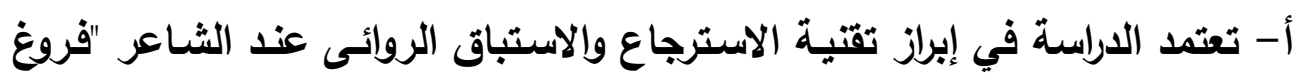

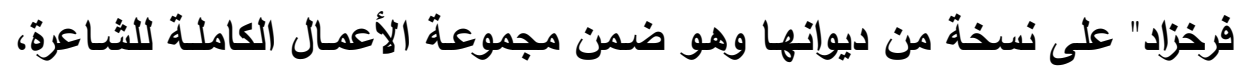

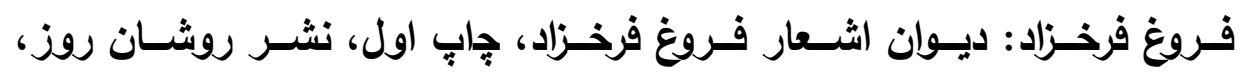

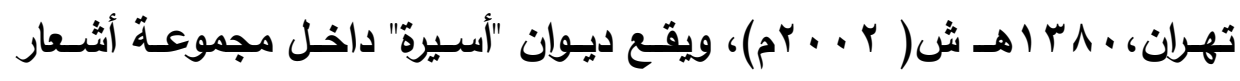

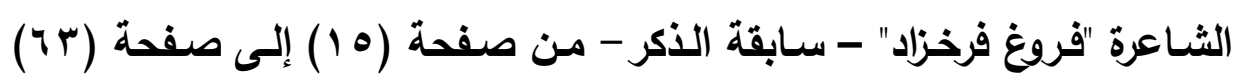
ويضم الديوان ( ع r) قصيدة.

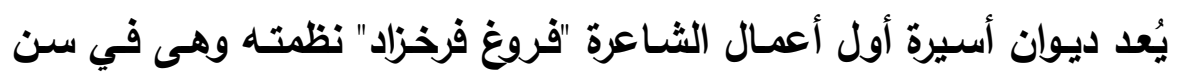
السابعة عشر من عمرها، ويُعد الديوان بثكل عام تجربـة شخصية لحياة الثـاعرة

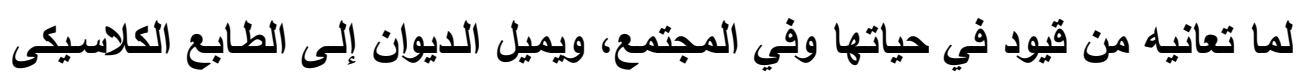
في أسلويه الثعرى خاصة في لغته الرومانسية والعاطفية مثل توظيف فئ الألفاظ مثل ولثيل

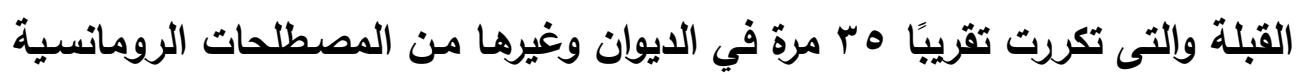

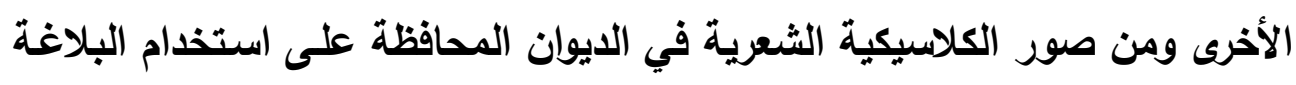

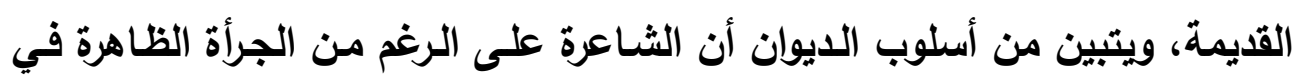


قصائد ها إلا أنها كانت تخثى وتتخوف من تقبل شعرها ومع ذلك يمثل هذا الديوان

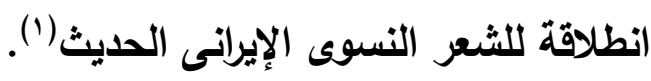
ب- تعتمد الاراسة في إبراز تقنية الاسترجاع الروائى عند الثاعر "أمل دنقل " على نسخة من ديوانـه وهو ضمن مجموعة الأعمـال الكاملـة للثـاعر أمـل دنقل:

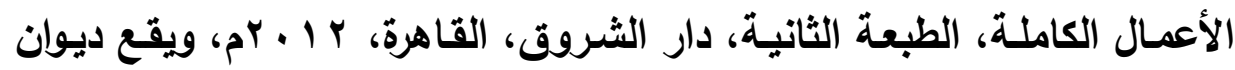

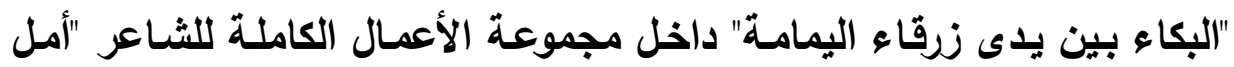

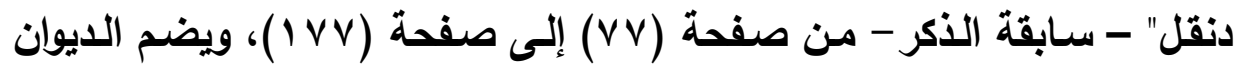
ديباجة شعرية و(1 1 ) قصيدة.

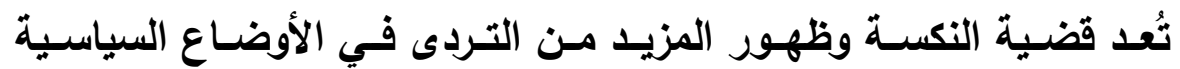
الداخليـة، والخارجيـة، والأوضـاع الاجتماعيـة، والاقتصـادية المصرية هـى القضـية الأساسية لديوان "البكاء بين يلى زرقاء اليمامـة"، وتدور أغلب مضامين قصائد

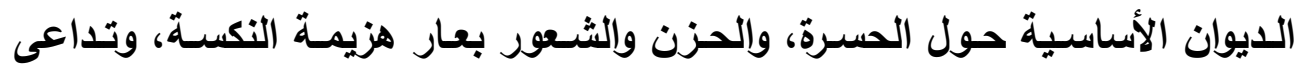

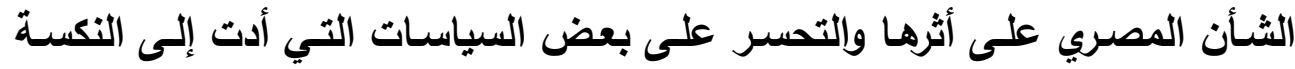

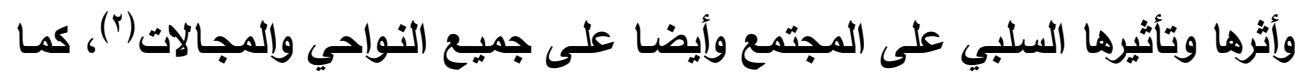
أن الثـاعر "أمـل دنقل" ينتمس إلى جيل السبعينيات وهو الجيل الذي بـأت فيـه الاشتراكية العربية تطبق ويدأت آثارها السلبية تظهر في المجتمع، وإنعكس ذلتك في لئي ديوان "البكاء بين يدى زرقاء اليمامـة" وهو من أهم إنتاج هذه المرحلة في حياة

(1) كلاله هنرى و عصمت اسماعيلى: سلطه وعصيان در زيان فروغ فرخزاد (خوانش شعر فروغ

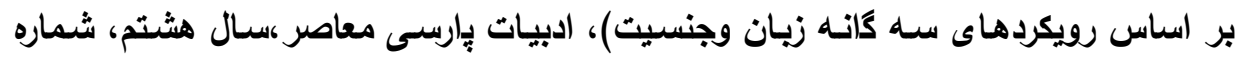

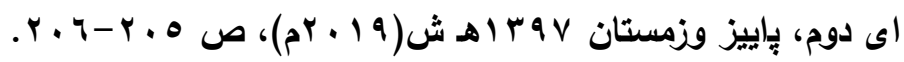

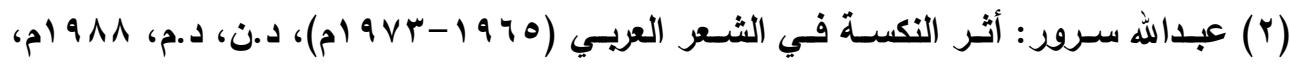

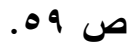


الثاعر "أمل دنقل" وفي الثعر المصري بصفة عامة، وأثشار إلى ذلك الثـاعر "أمل

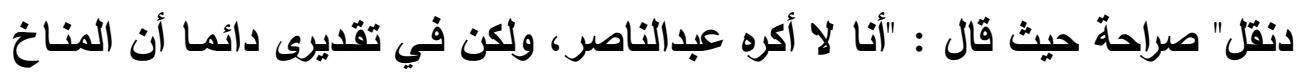

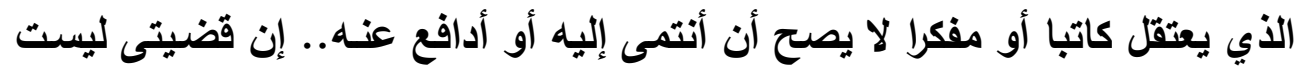

عبدالناصر حتى ولو أحبيته ولكن قضيتى دائما هى الحرية"|(1). أولا: تعريف تقنية الاستزجاع الرواني وأنواعها وأهميتها: تُعد تقتية الاسترجاع الروائى من أهم أثثكال المفارقات الزمنية داخل النص

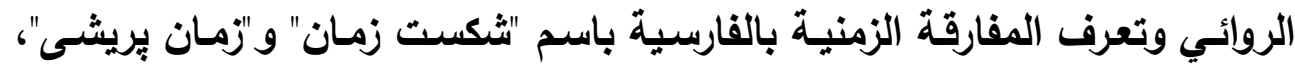

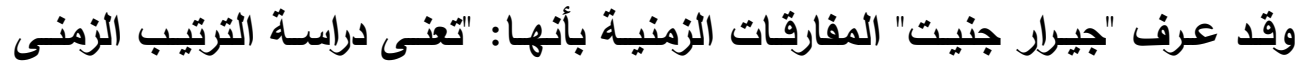

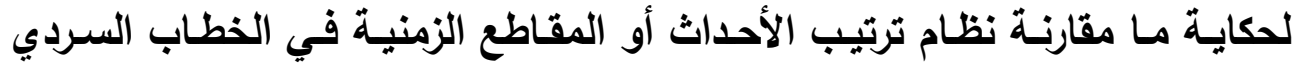

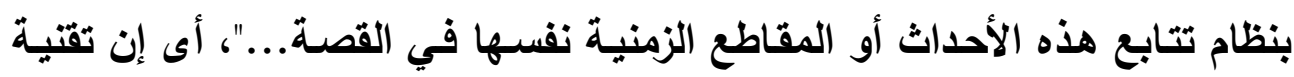

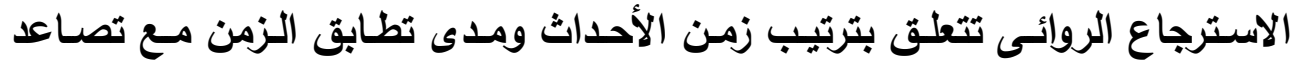

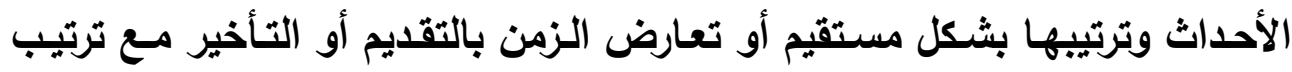

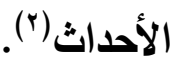

ورد تعريف تقتية الاسترجاع في "معجم المصطلح السردي" بثلاثة معانٍ

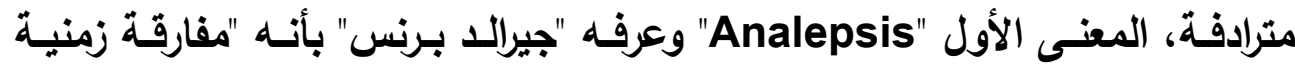

(1) عبلـة الروينى: الجنوبي (سيرة أمل دنقل)، الطبعة الأولى، دار سـعاد الصباح، الكويت، (1) - (r)

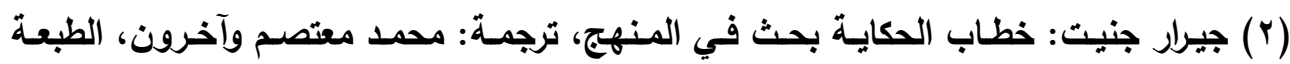

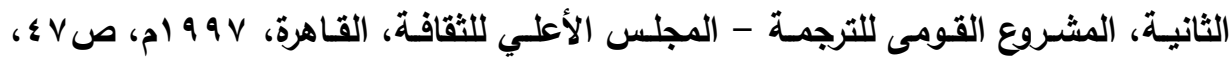

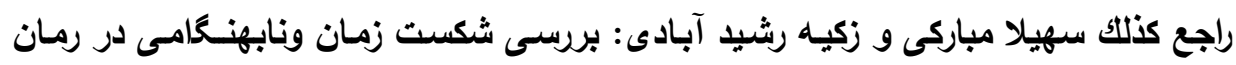

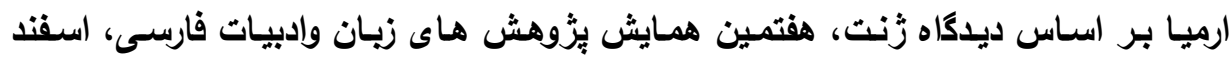

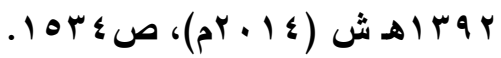


تعيدنا إلى الماضسي بالنسبة للحظة الراهنة، استعادة لواقعة أو وقائع حدثت قبل

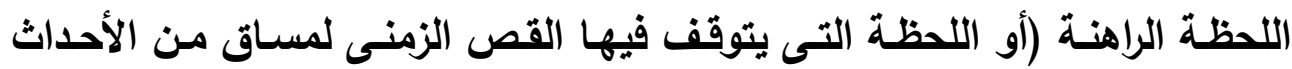

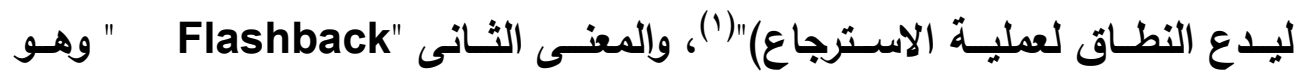

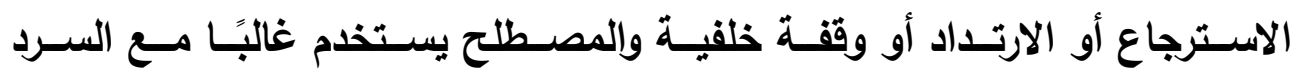

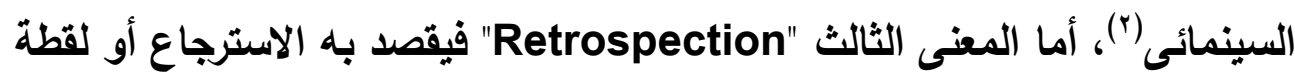
خلفية أو التوقف عند نقطة سابقة، أو الانتقال إلى الخلف("). وتُعد تقنيـة الاسترجاع الروائسى بأنها أكثر تقنيات عنصر الزمن شيوعًا واستـذامًا في الأعمـال القصصية الفارسية وتعرف في الفارسية باستم "كَنشتهـه

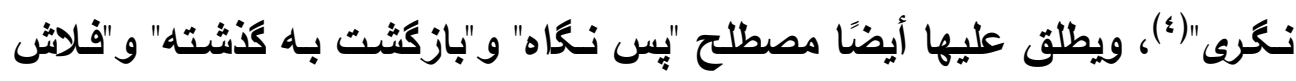

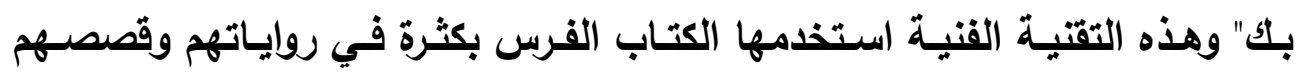

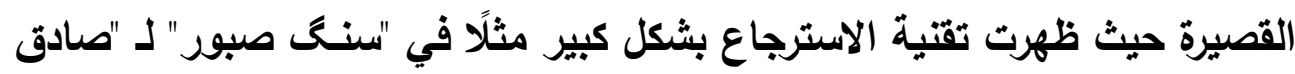

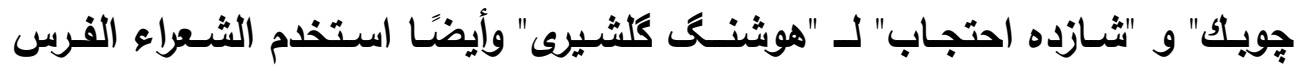

(1) جيرالا برنس: المصطلح السردي (معجم المصطلدات)، ترجمة عابد خزندار، الطبعة الأولى،

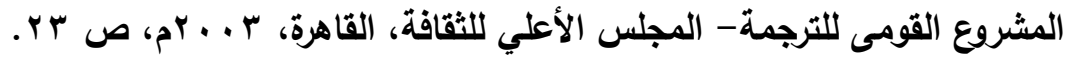

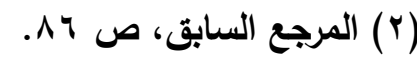

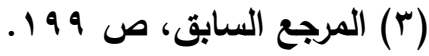

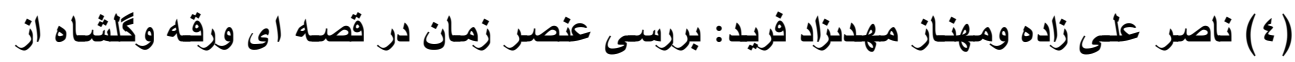

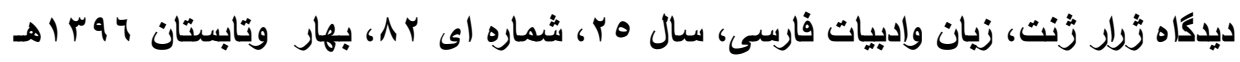

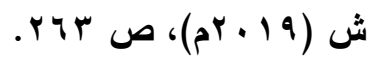


تقنية الاسترجاع الروائى في أثـعارهم حيث وظفها الثـاعر "سـهراب سبهرى" على إنى

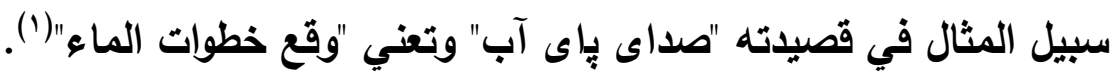
ويهاف الروائى من توظيف تقتية الاسترجاع الروائس داخل عمله الروائسى

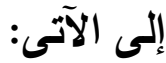

1 - يستخدم الراوي تقتية الاسترجاع ليصل بعض الحلقات المفقودة في الرواية.

r - يعرف القاريء بماضي الثخصيات وتاريخها ـ

r- يُعد الاسترجاع نوعا من أنواع مشاركة القارئ للنص من خلال جعل المتلقي

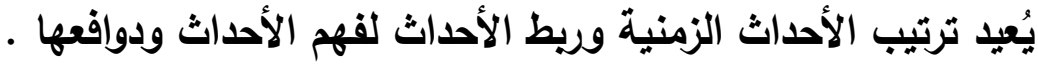

ع - يمـزج الاسترجاع حلقـات الزمن بشكل جيد فالماضسي والحاضـر حلقة واحدة وبينهما علاقة متثابهة للمستقبل أيضًا (؟).

أمسا عن أنواع الاسترجاعات فقد حدد "جيرار جينت" ثلاثة أنواع أساسية

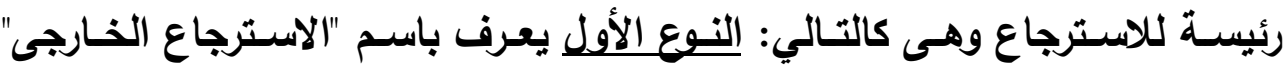
ويعرف بأنه استعادة أحداث العودة إلى ما قبل بداية الحكى حيث يعود فئه فيه السارد

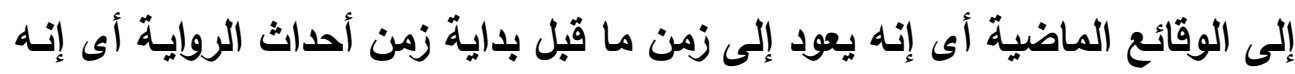

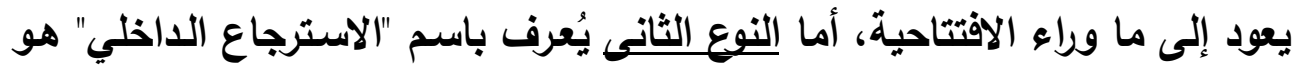

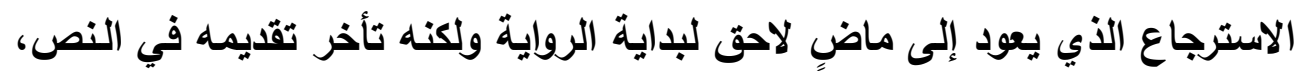

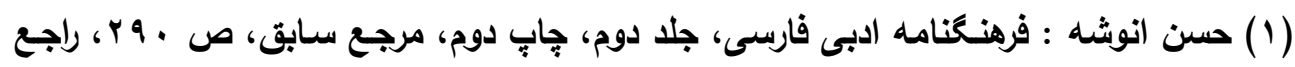

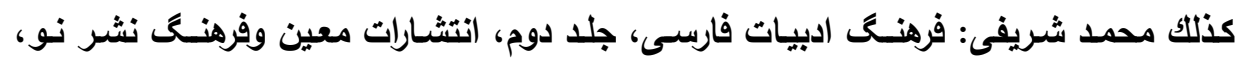

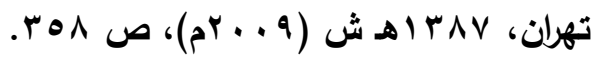

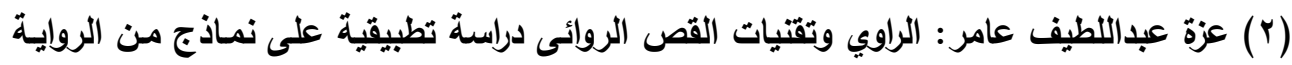

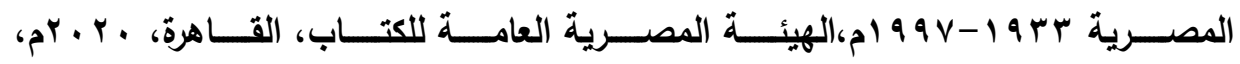


بمعنى أوضح هو استعادة أحداث وقعت ضمن زمن الحكايـة أي بعد بدايتها، وأخيرًا النوع الثالث يطلق عليه "الاسترجاع المزجى" وهو يجمع بين النوعين السابقين حيث

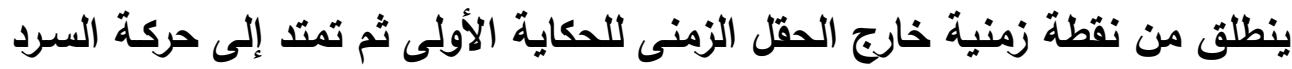

حتى تتضم إلى مسار حركة الحكاية الأولى وتتعداه(').

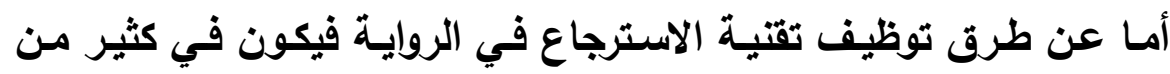

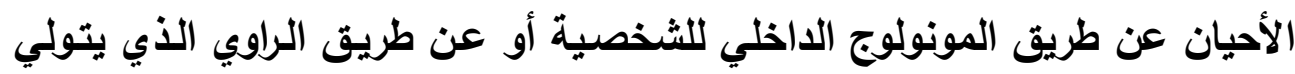
القص ويعرف ماضي الثخصية(؟).

\section{ثانيا: تقنية الاسترجاع الرواني في الديوانين:}

ا- تقنية الاسترجاع الروانى في ديوان "أسيرة":

يمثل ديوان "أسبيرة" للشـاعرة "فروغ فرخزاد" بدايـة أعمالها الشـعرية وكان الايوان بكل مـا تحمله نصوصـه من أفكار، وموضوعات ولغة شعرية هو انعكاس

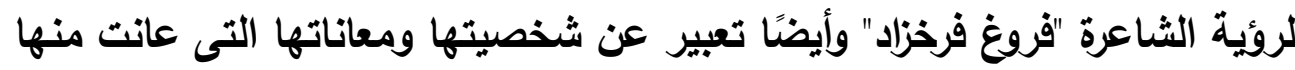
في ظل المجتمع الإيرانى المنظلق، وكان شعرها بداية من ديوان "أسيرة" شعبرًا صـادمًا

(1) نفيسة معتوق: البنية الزمنية في رواية "يوميات نائب في الأرياف" لـت"توفيق الحكيم"، رسالة

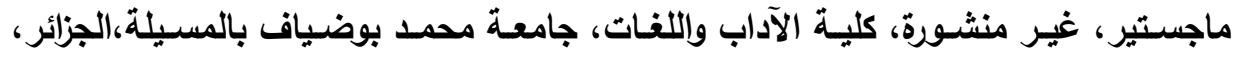

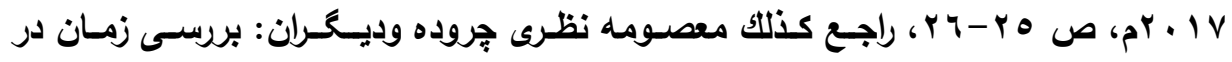

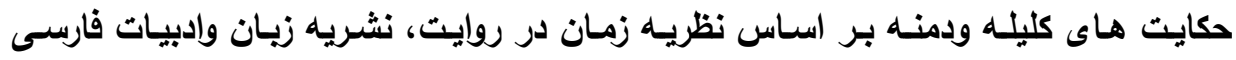

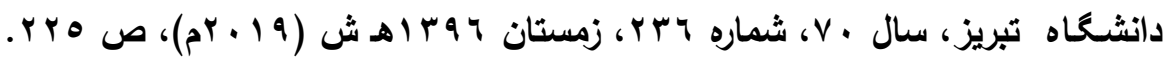

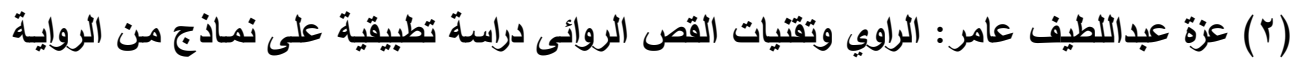

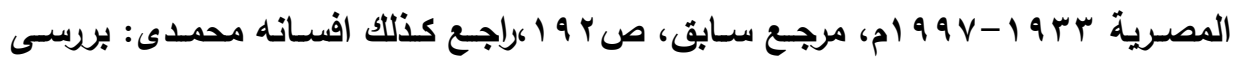

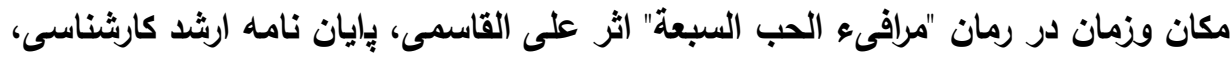

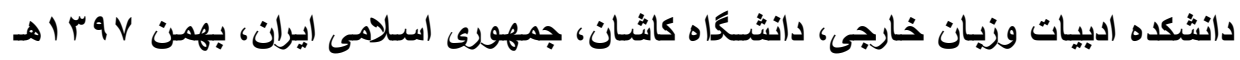

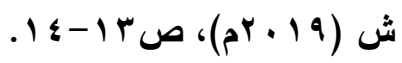




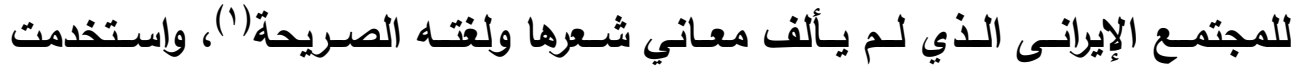

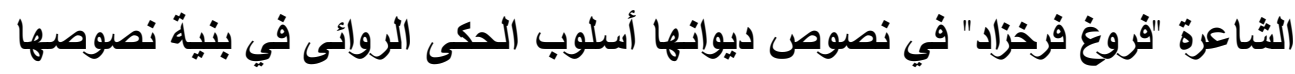

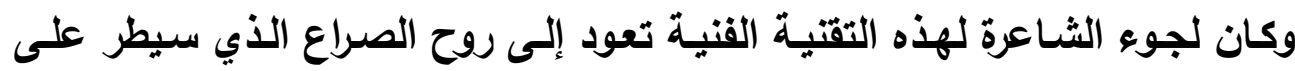

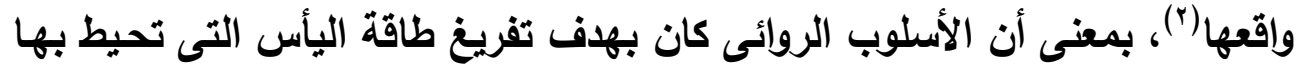

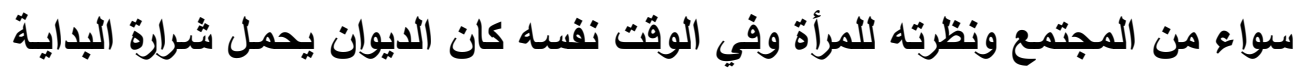
لفكرة التمرد والتى سوف تظهر في الأعمال الثعرية التالية للثاعرة . ولقق اهتمت الشاعرة "فروغ فرخزاد" في ديوانها "أسيرة" بعنصر الزمن وكانت

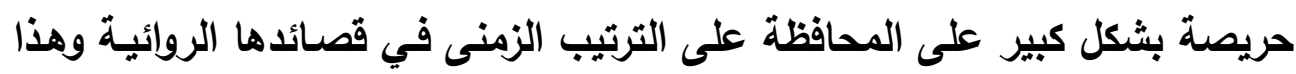
جزء من السمات الكلاسيكية في ديوانها، ومن تلك القصائد قصيدة "دختر ويهار التهار وتعنى "الفتاة والربيع" حيث تقول: "جلست الفتاة بجوار النافذة وحيدة وقالت التهن / يافتاة

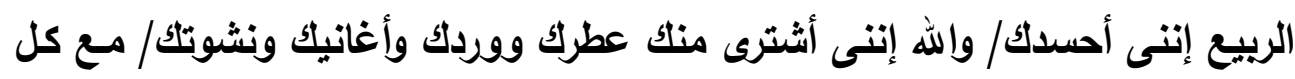

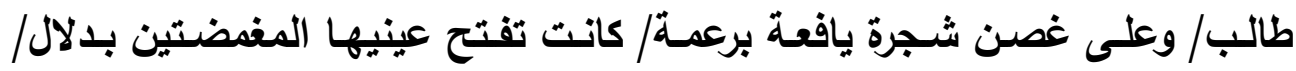
وكانت تغسل شعر رأسها بمياه فضية اللون/ وكذلك تلكك الأجنحة الرقيقة الجميلة

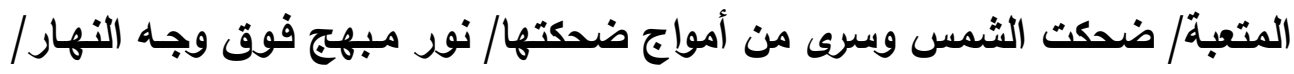

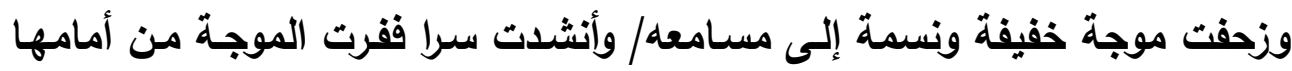

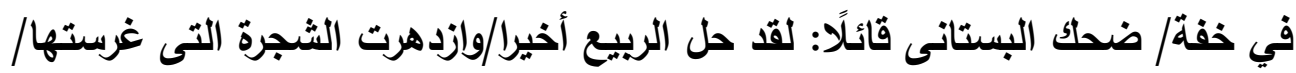

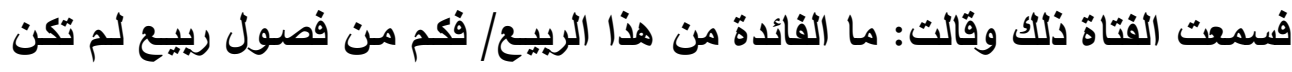

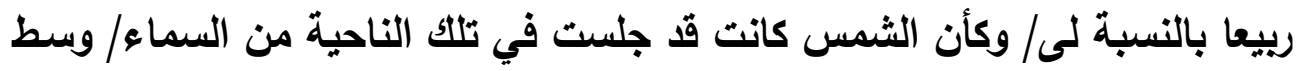

(1) إبراهيم الدسوقي شتا: الثـعر الفارسي الحديث دراسـة ومختارات، الطبعة الأولى، الهيئة

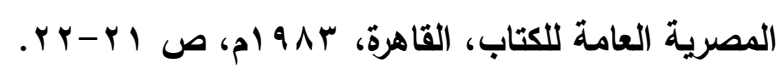

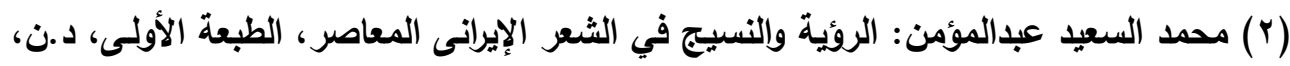

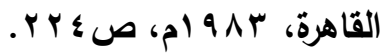


مجمر مـن اللام وهـ عطثــ/ وكـان النهار يمضـي وكانت الفتاة جالسـة بجوار

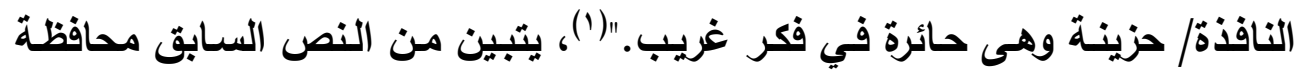

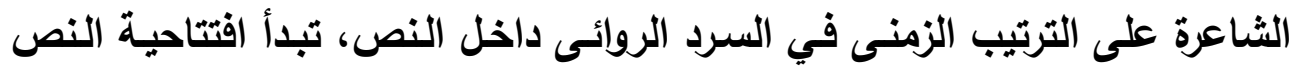
زمنيًا في وقت الصباح وتنتهى في وقت الغروب وبين هذين الزمنين حافظت الثاعرة على الترتيب الزمنى، وهذا الأسلوب هو أسلوب تقليدى في النظم الثـعرى

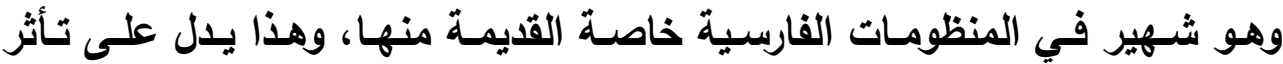

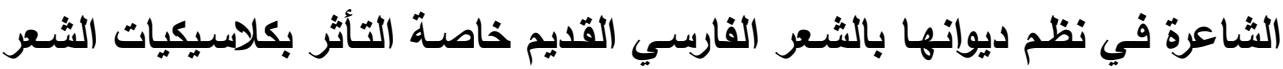

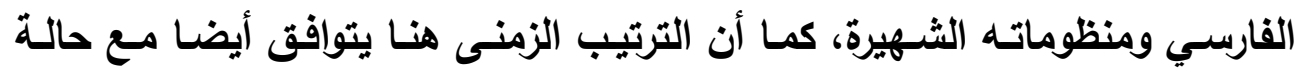

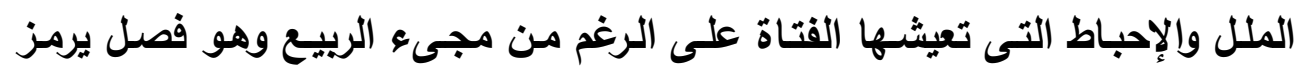

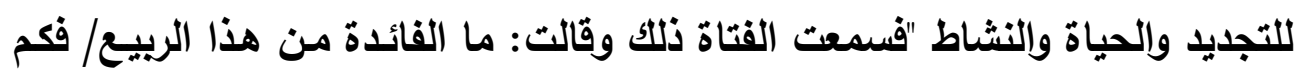

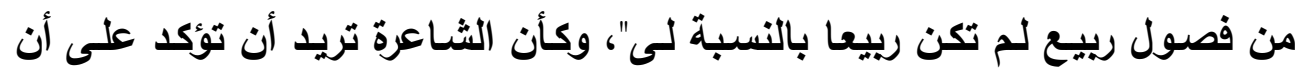

(1) الترجمة العربية نقلا عن فروغ فرخزاد: مختارات من أشعار الثناعرة الإيرانية فروغ فرخزاد، الثرادية

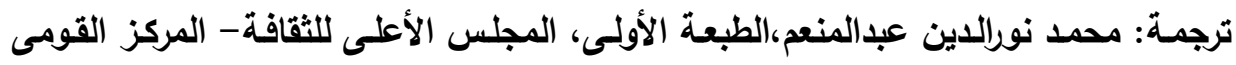

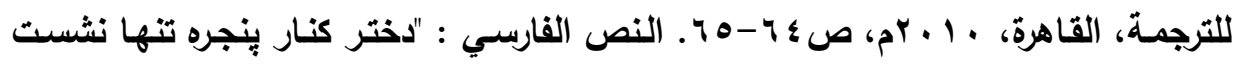

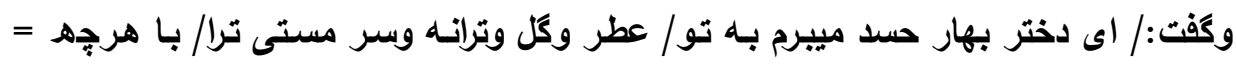

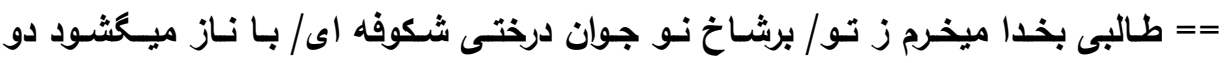

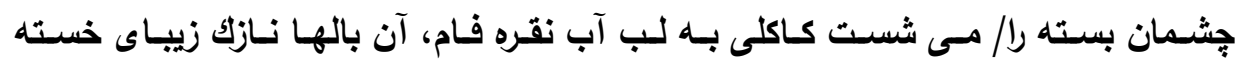

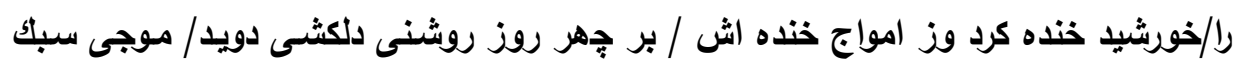

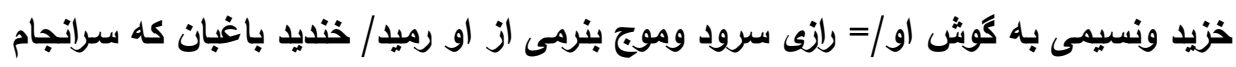

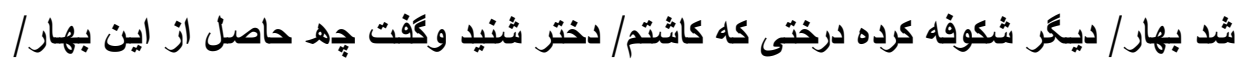

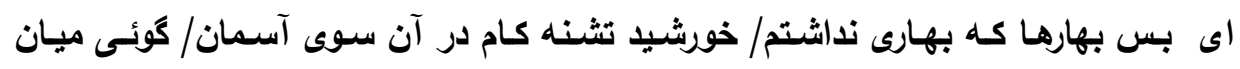

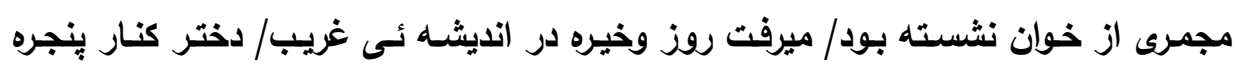

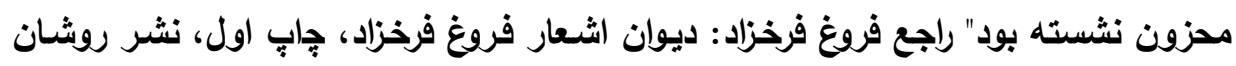

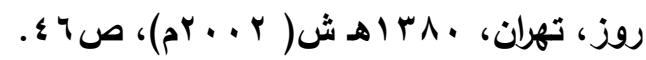


اللجوء للانحراف الزمنسى وانزياحاته بتقنياته المختلفة مثل الاسترجاع الروائسى يُعد تعارضًا لحالة الملل وحياة التكرار الحزينة التى تحياها. ولقد مثلت تقنيـة الاسترجاع الروائسى في ديـوان "أسيرة" للثـاعرة "فروغ فرخزاد" ظاهرة واضحة وتعددت مواضـع توظيف الثـاعرة لتقتية الاسترجاع الروائسى داخل الـيوان ويسـي الباحث بواسـطتها إلـي الـريط بين أسباب توظيف تقتيـة

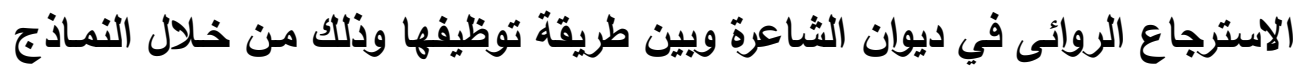

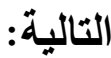

يبدأ الترتيب الزمنس للحدث في قصيدة "بيمـار" وتعنى "المريض" بالوقت المضارع على وصف الراوي/الثاعرة لحالة ابنها المريض فتقول: "طفل مريض نائم بين ذراعى /بوجنتين محمومتين..محمومتين/ويخصلات

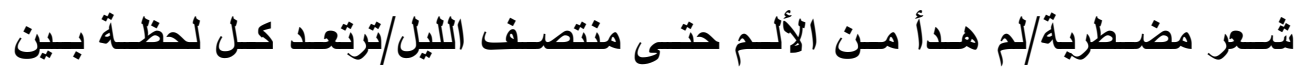

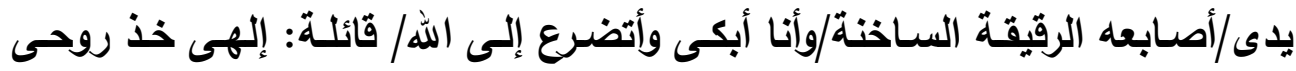
وخفف عنه الألم/وأحيانا وسط الخوف من الوحدة وقلقها/أسأل نفسي ماذا ستكون

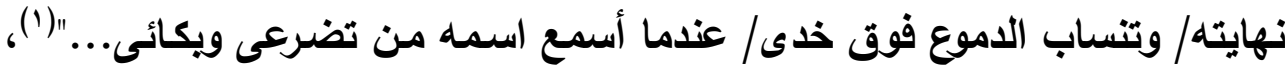

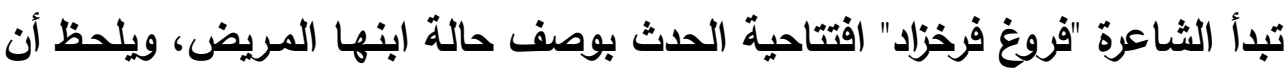

(1) الترجمة العربية نقلا عن فروغ فرخزاد: مختارات من أثعار الثـاعرة الإيرانية فروغ فرخزاد،

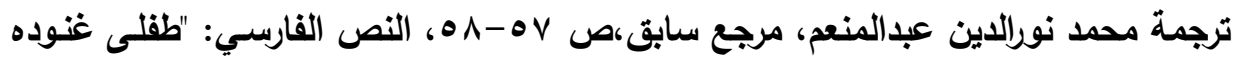

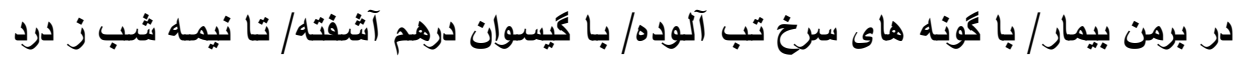

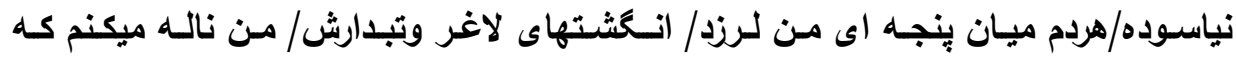

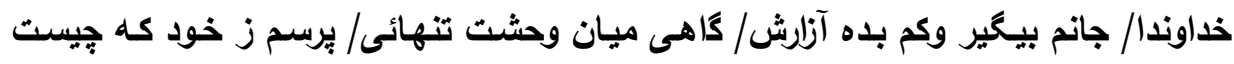

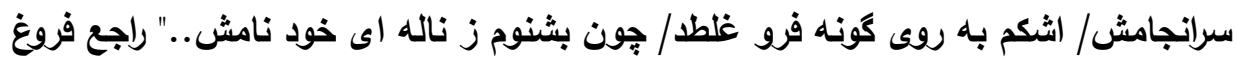

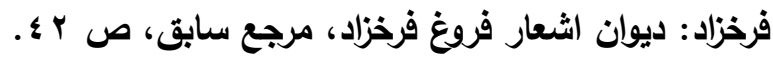




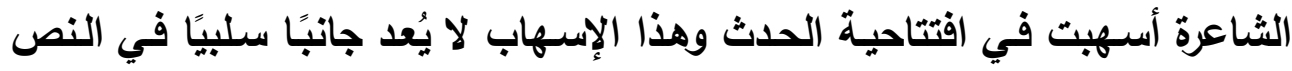

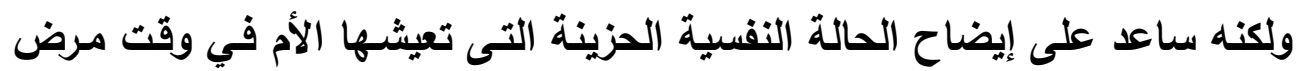
ابنها وذلك بتوظيف مجموعة من الجمل التى تعمق الحالة النفسية للنص. أما عن توظيف تقنية الاسترجاع الروائى فقد وظفتها الثاعرة في الجزء قبل الأخير من النص حيث تقول : "لقد تذكرت عندما كان يطلب منى قبلة/وهو يضحك

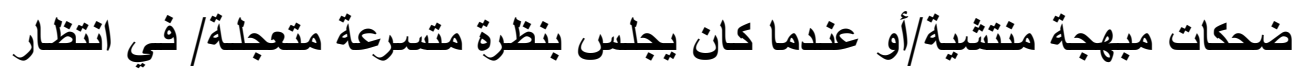

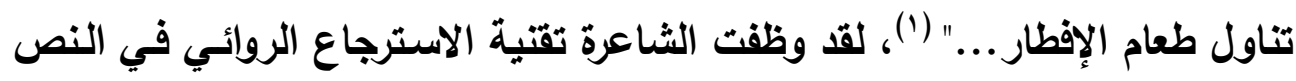

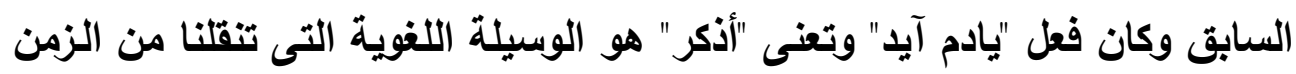

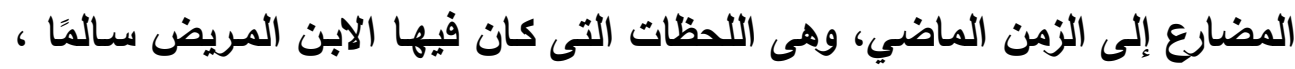

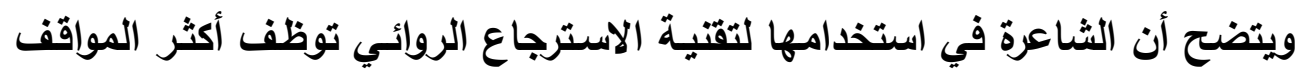

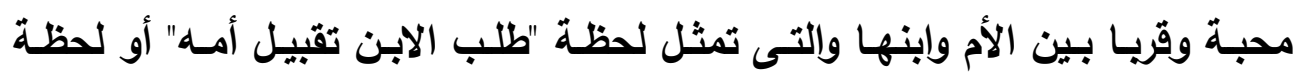

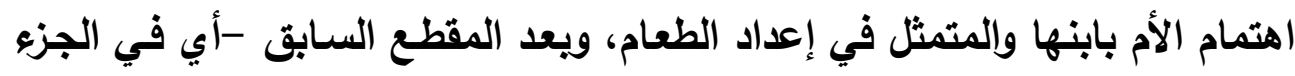

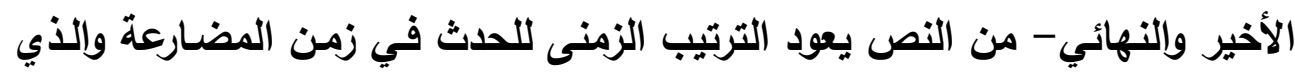

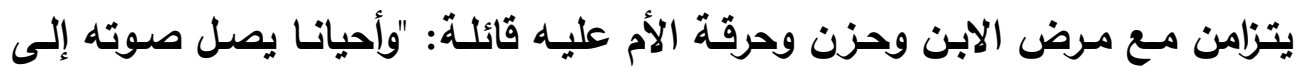

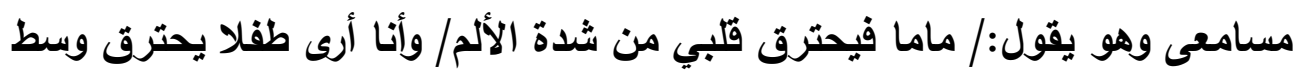

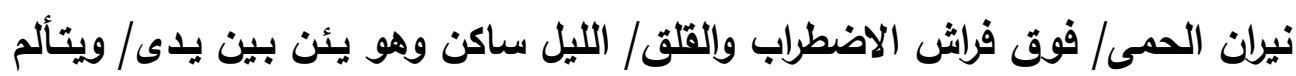

(1) الترجمة العربية نقلا عن فروغ فرخزاد: مختارات من أثعار الثـاعزة الإيرانية فروغ فرخزاد،

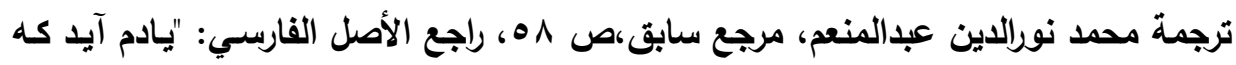

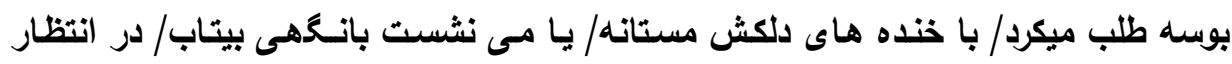

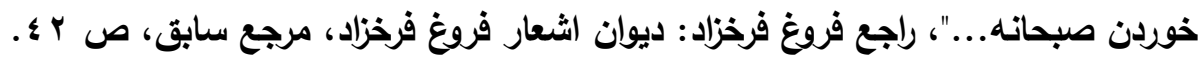


مسن شـدة المـرض/ بينمـا تضـكك مـن اضـطرابى وخـوفي/ دقـات سـاعة الحسائط

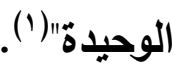

ويرى الباحث أن سبب توظيف الثـاعرة "فروغ فرخزاد" لتقنية الاسترجاع

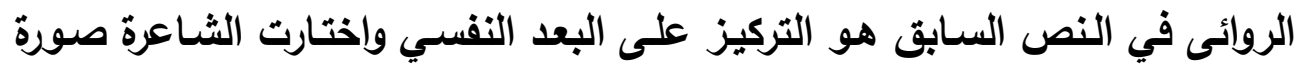

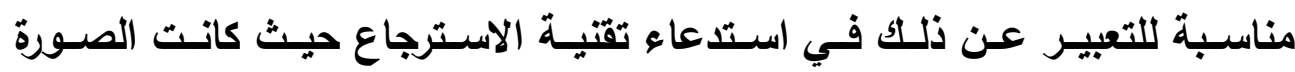

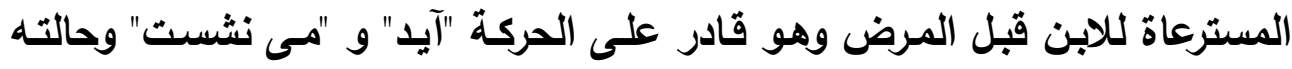

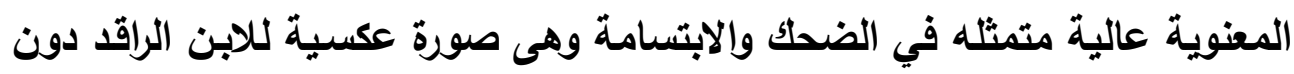

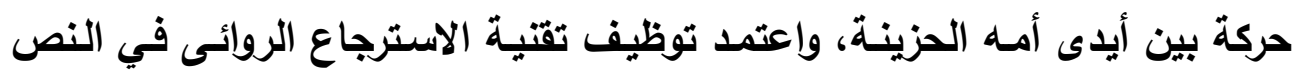

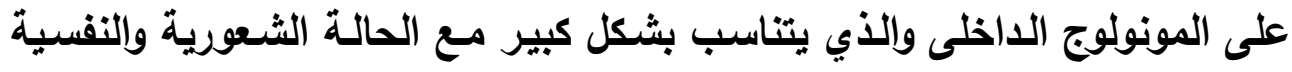
للراوي/الثاعرة وحالتها في وقت مرض ابنها وخوفها عليه. وتبين في قصيدة "بازكثتت" وتعنى "الرجوع" أن توظيف تقنيـة الاسترجاع

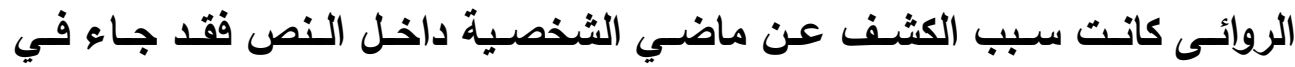

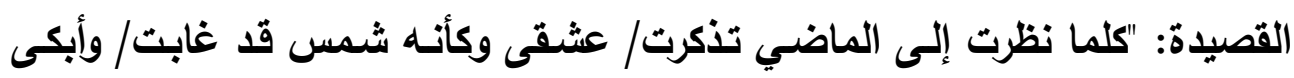

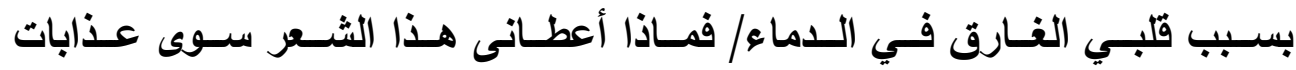

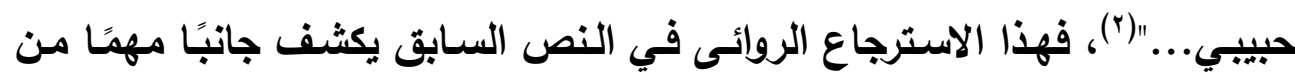

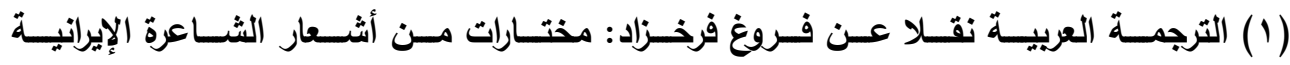

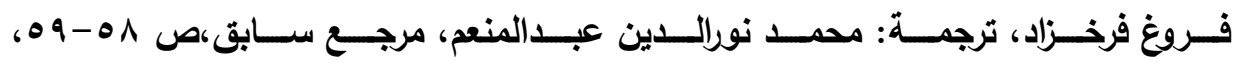

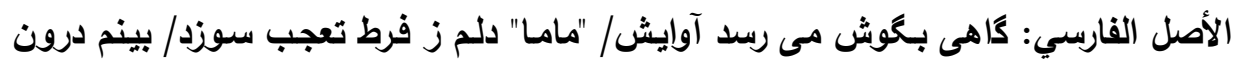

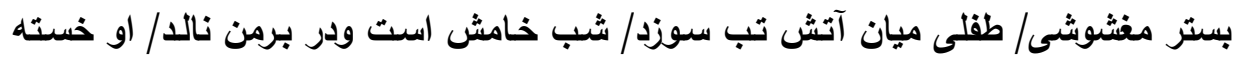

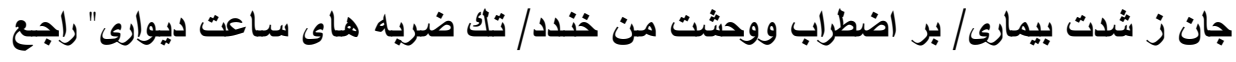

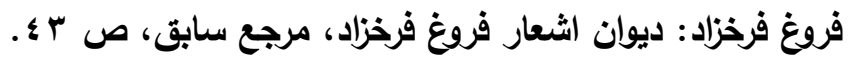

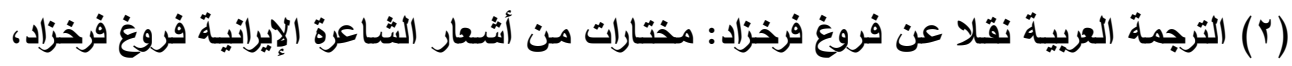

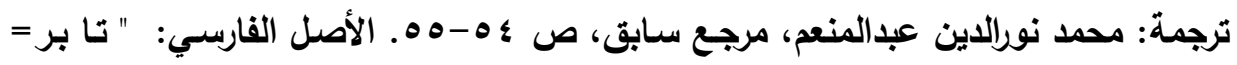


جوانب شخصية الثاعرة "فروغ فرخزاد" التى تمثل في شعورها الدائم بالتقيد وعدم

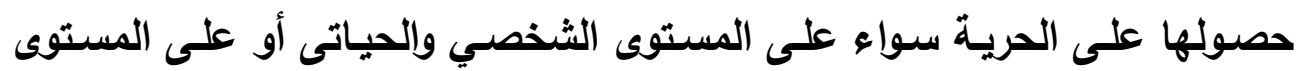

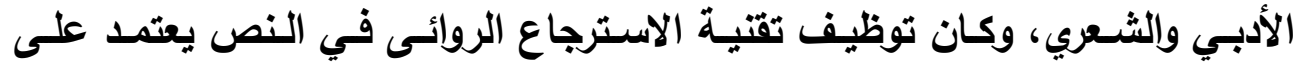

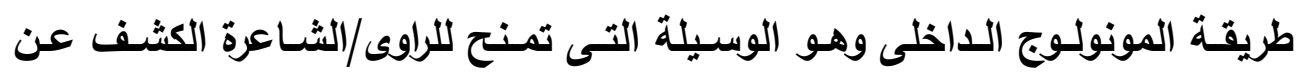

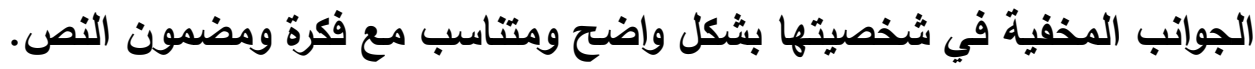
ولقد كانت الضرورة الفنية هى السبب الثالث الذي بسبيه لجأت الثـاعرة

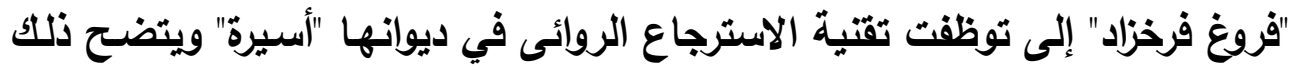

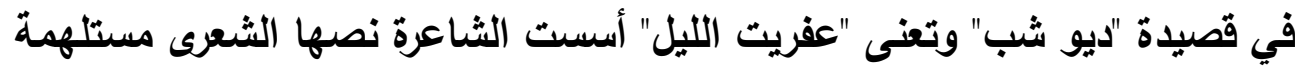

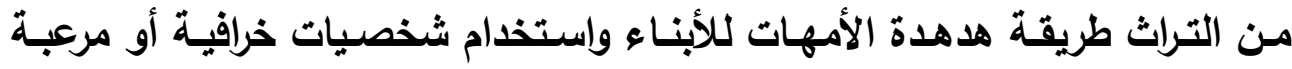
لتنويمهم وفي مفتتح القصيدة تقول الثاعرة:" نم يا ولاى الصغير / وأغمض عينيك فقد أقبل الليل/ أغمض عينيك فإن عفريت الليل هذا/ قد جاء وكفه ملوثنة بالدماء

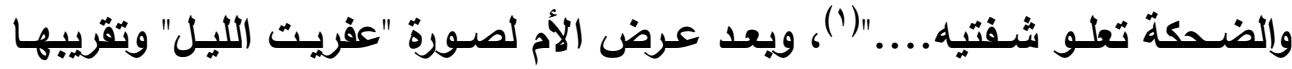

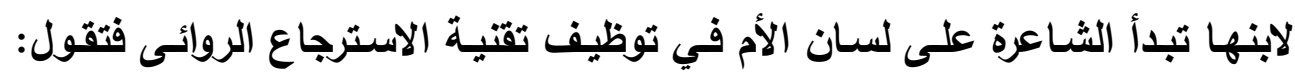

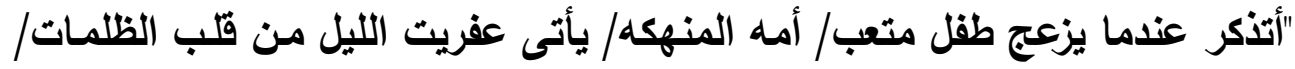
فجأة ويأخذ الطفل/ ويهتز زجاج النوافذ/ بمجرد مجيئه صـارخا/ ويصيح قائلا: أين مئن

= كَنته مينكرم عشت خويش را/ جون آفتاب كمشده ميآورم به ياد/ مينالم از دلى كه بـه

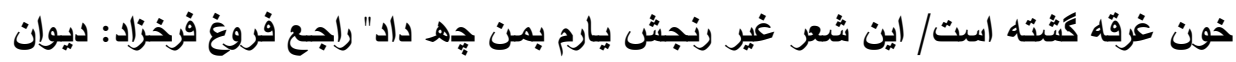

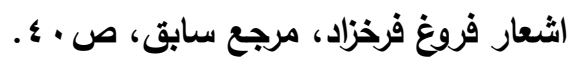

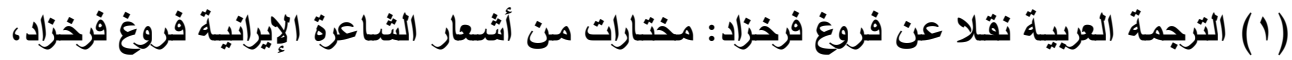

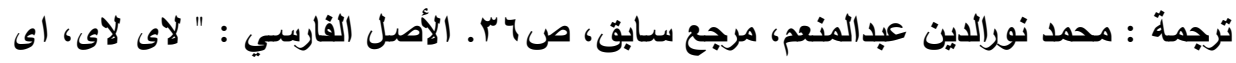

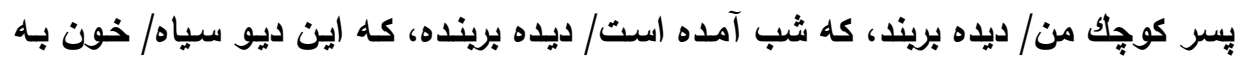

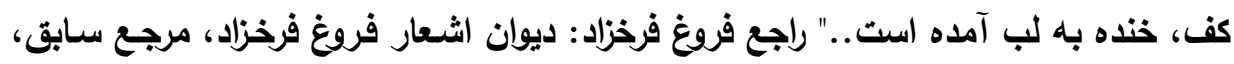


ذهب الطفل؟.."(')، فالشاعرة تمزج ما بين وصف "عفريت الليل" مع استدعاء موقف

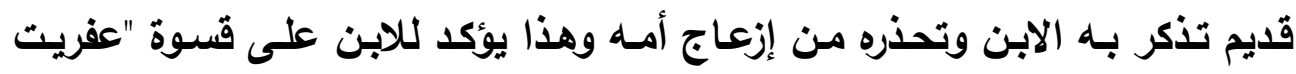

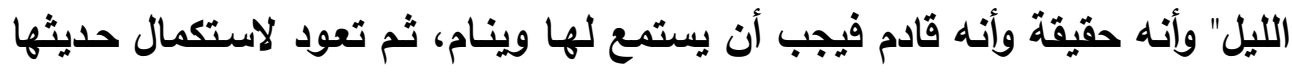

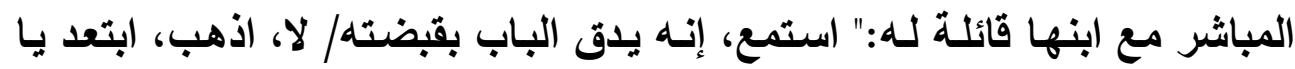

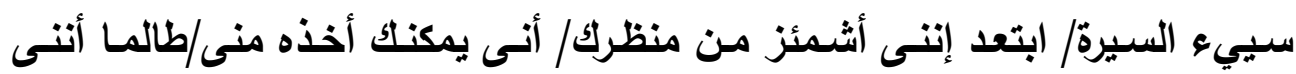

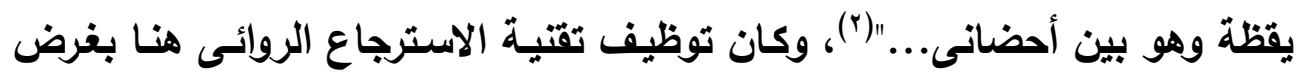

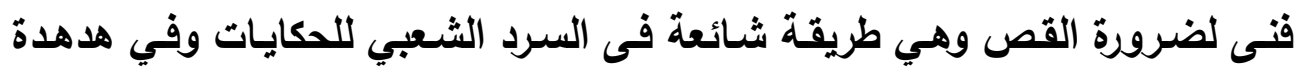

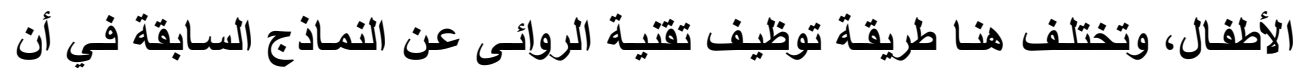

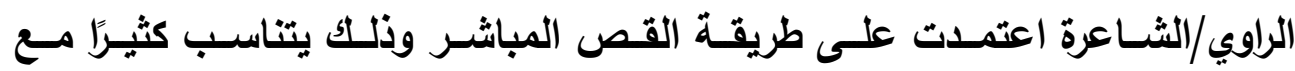

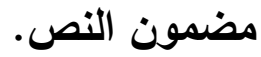

ويتبين من النماذج السابقة أن تقتيات الاسترجاع الروائى في ديوان "أسبرة"

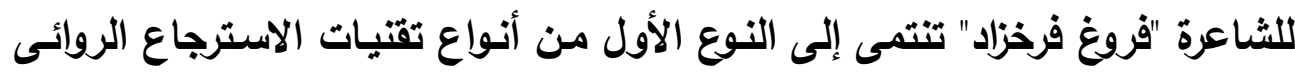

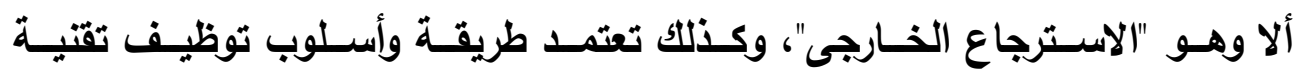

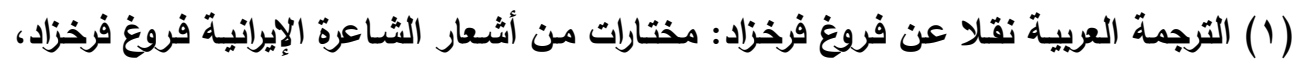

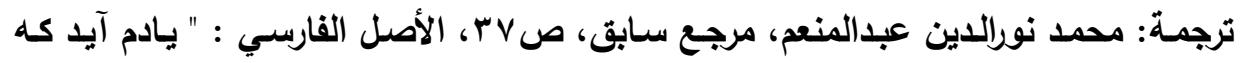

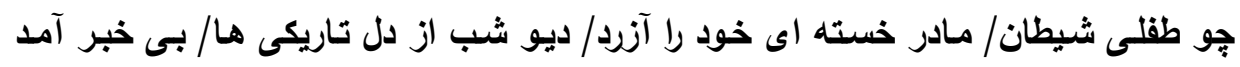

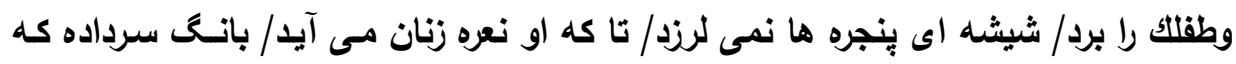

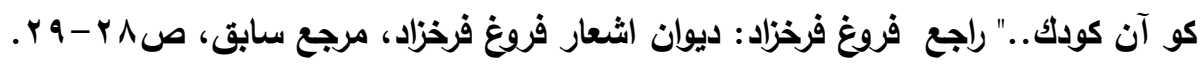

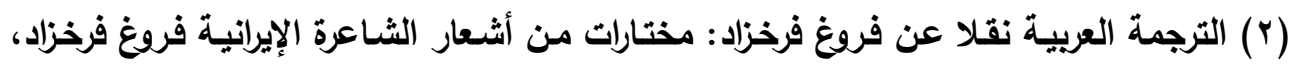

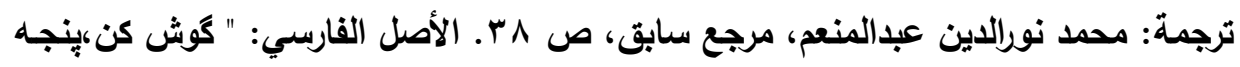

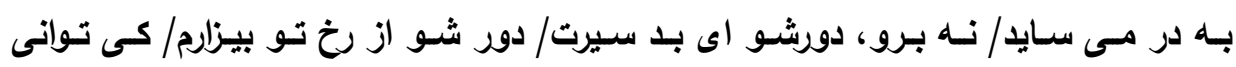

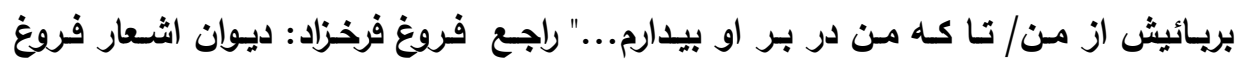

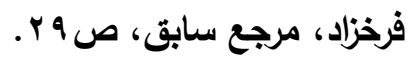


الاسترجاع الروائى في قصائد ديوان "أسيرة" على فكرة الترتيب الزمنى التقليدى بداية من افتتاحية النص، ثم تستخدم الثاعرة بعد ذلك تقنية الاسترجاع الروائسى في جزيء من النص ويكون ذلك إما لحالة شعورية أو لكثف عن أبعاد شخصية داخل النص

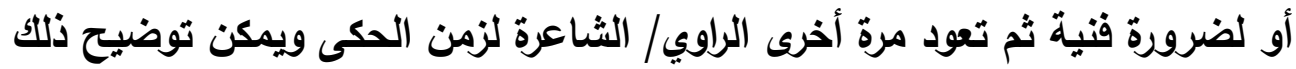
من خلال الرسم التوضيحي الآتي:
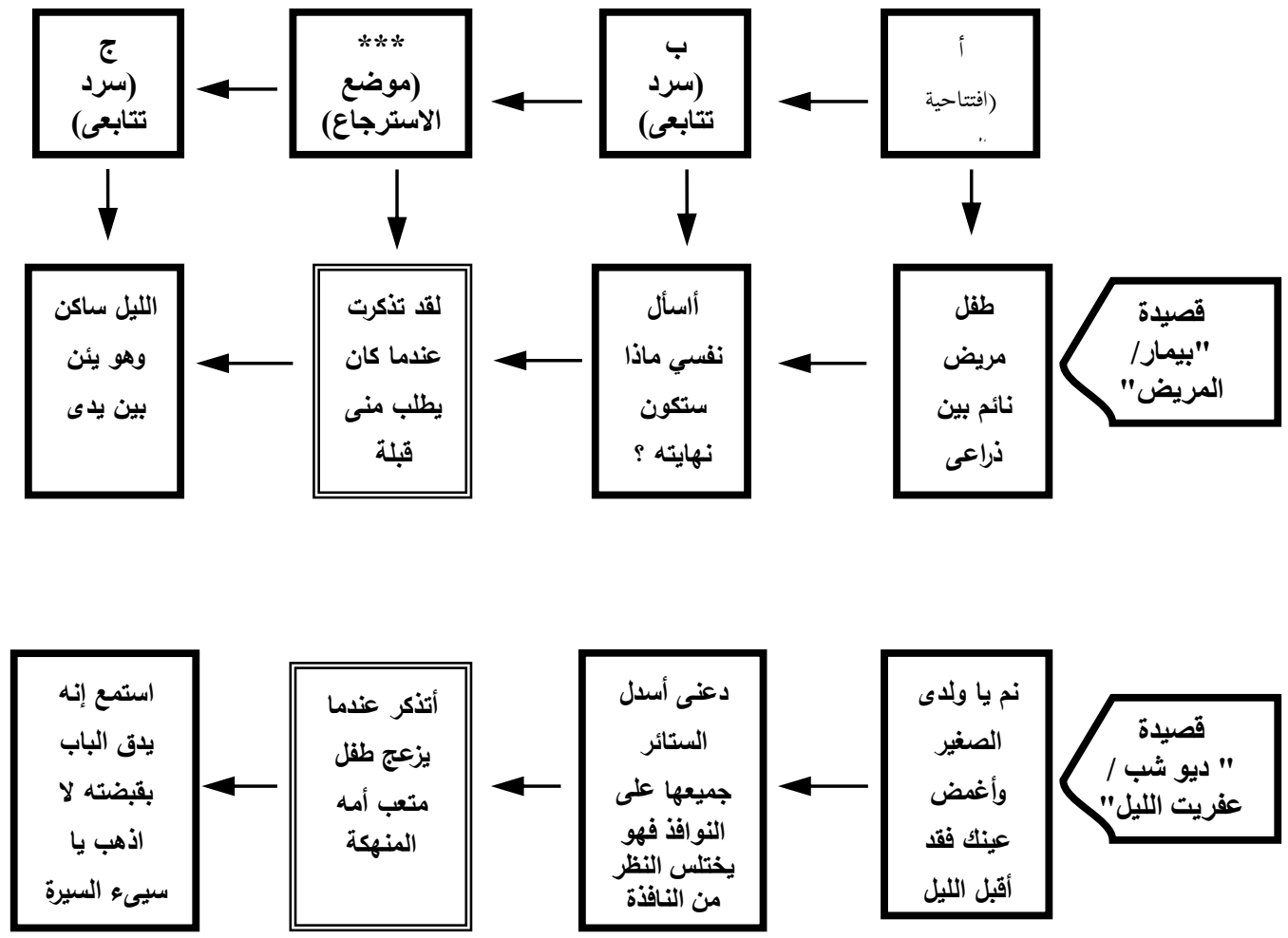
وعلى خلاف الطريقة السابقة في توظيف تقنية الاسترجاع الروائى حيث

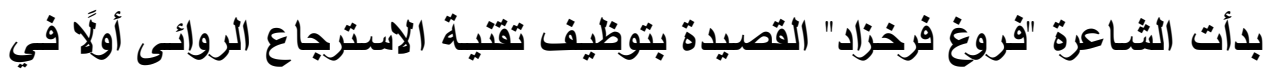

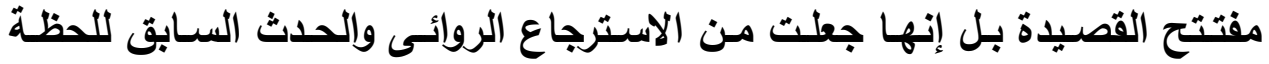

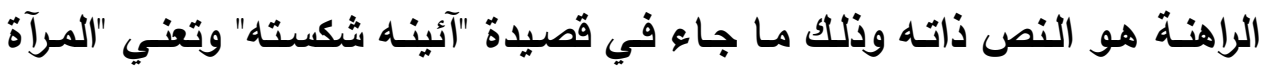

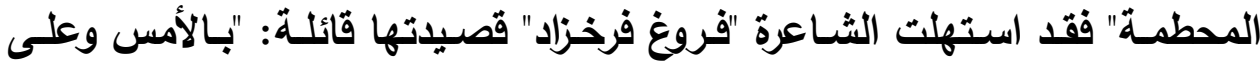

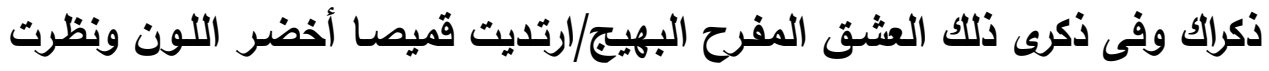

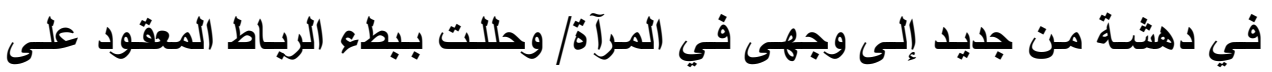

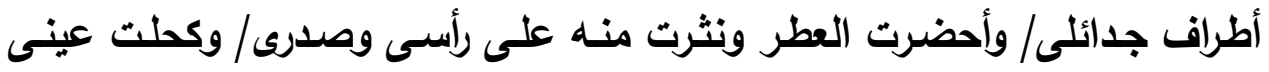

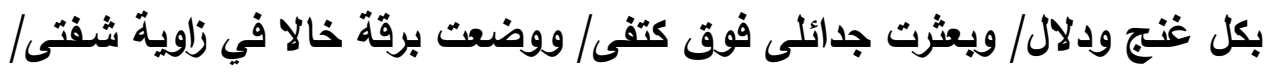

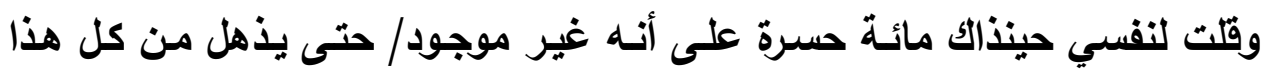

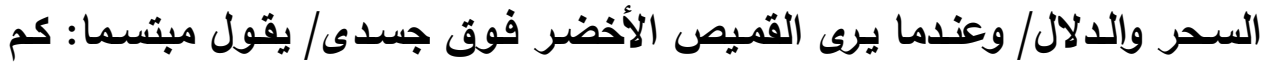

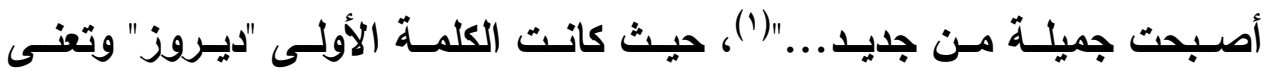

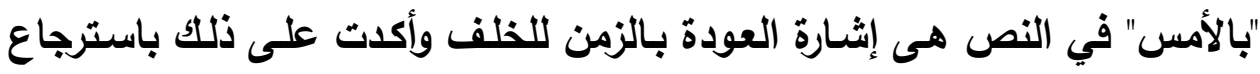

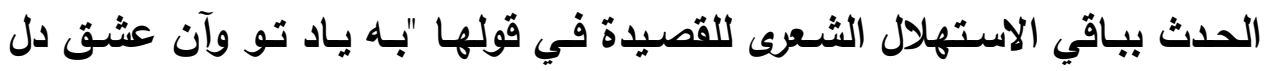
انكيز" وتعنى " وعلى ذكراك وفى ذكرى ذلك العثق المفرح البهيج".

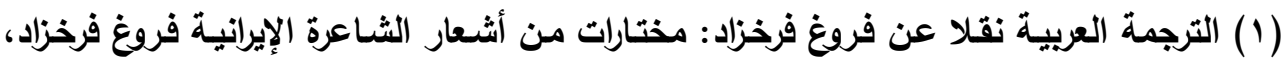

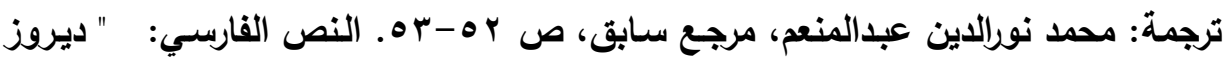

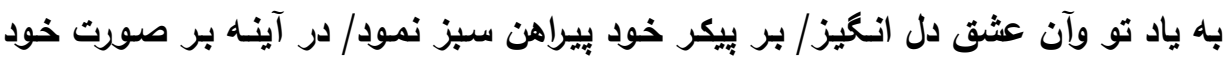

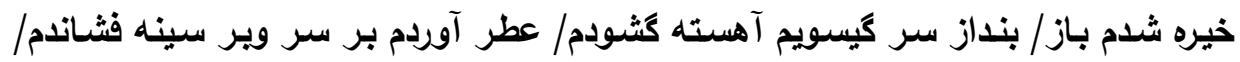

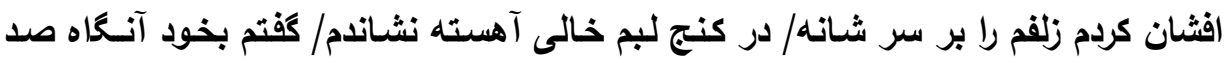

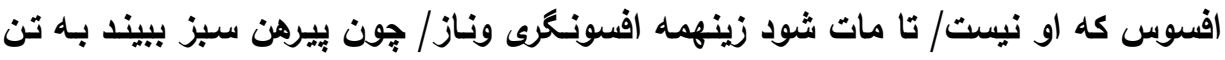

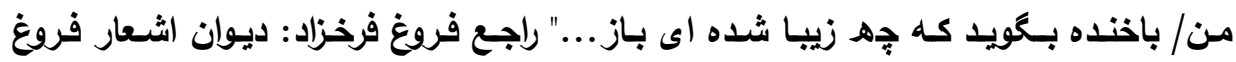

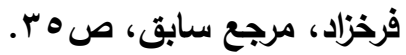


r- تقنية الاسترجاع الروانى في ديوان "البكاء بين يدى زرقاء اليمامة":

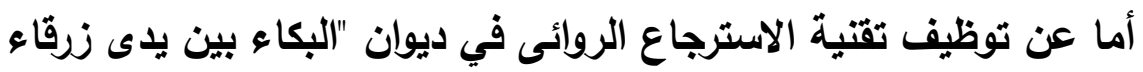
اليمامـة" للثـاعر "أمل دنقل" فقد مثلت ظاهرة بارزة في الديوان حتى إن عنوان

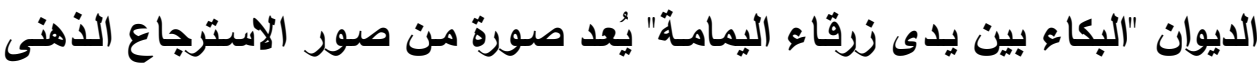

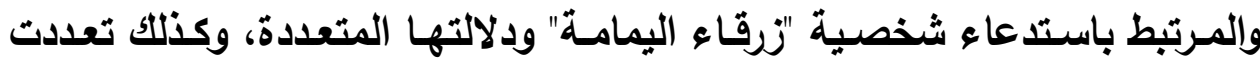
القصـائد الثـعرية التى وظف من خلالها الشـاعر "أمل دنقل" تقتيـة الاسترجاع

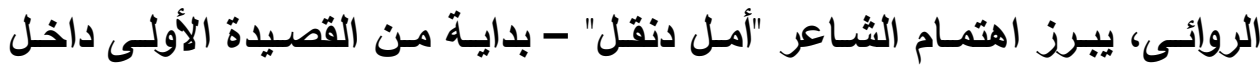

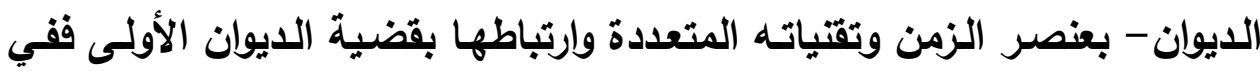

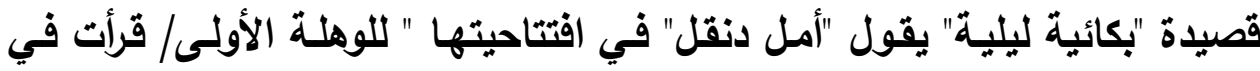

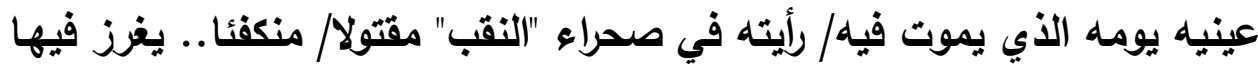

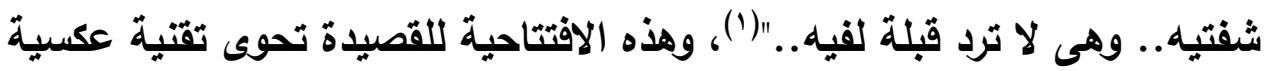

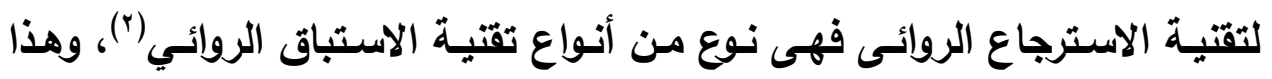

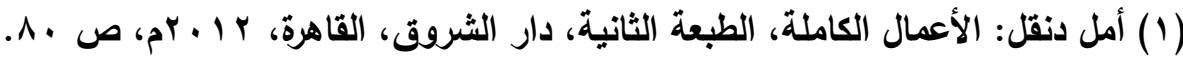

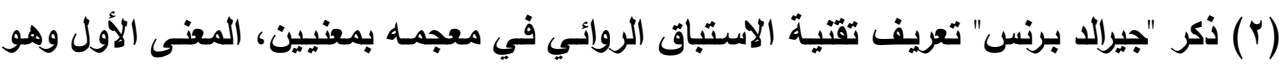
Anticipation"

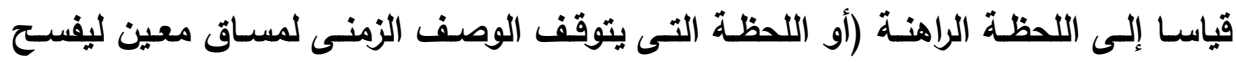
النطاق للتوقع"، أمسا المغنى الثانى فهو "Flashforward" ويغنس الاستباق أو تمهيد أو الو

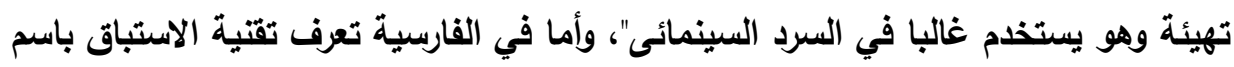

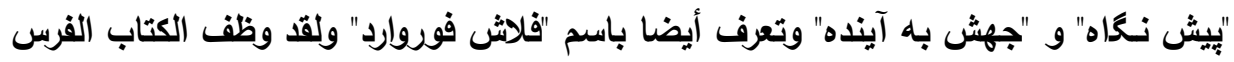

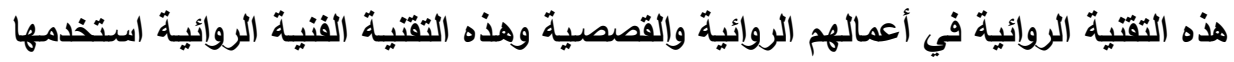

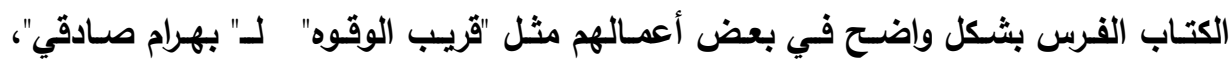

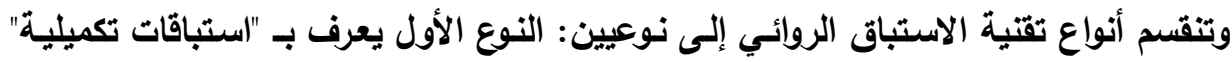

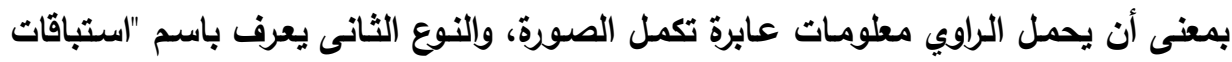

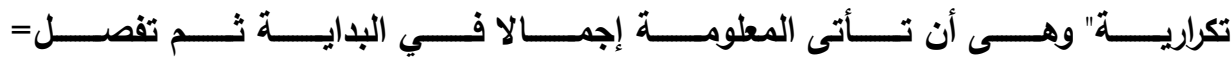


التوظيف الأولى والافتتاحى لتقتية الاستباق الروائى في القصيدة يؤكد على رؤيـة

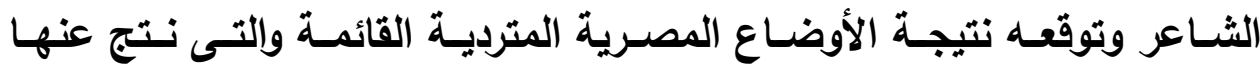

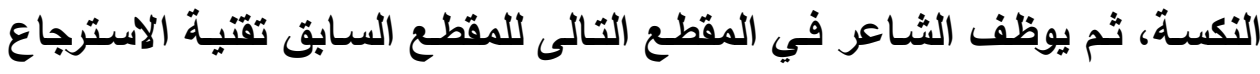

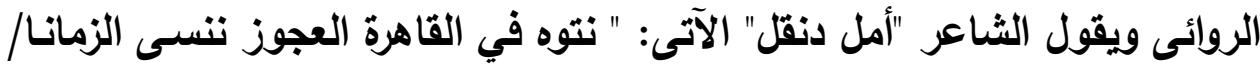

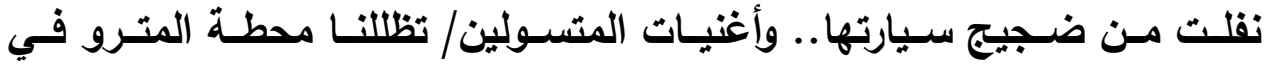

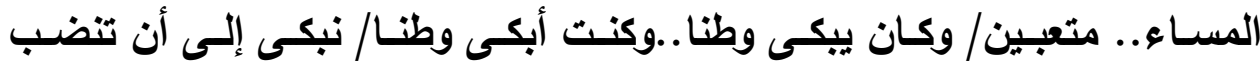

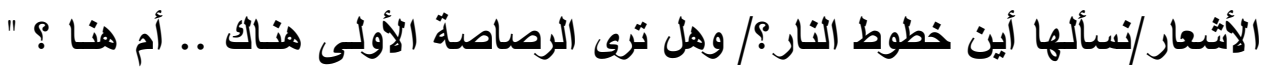

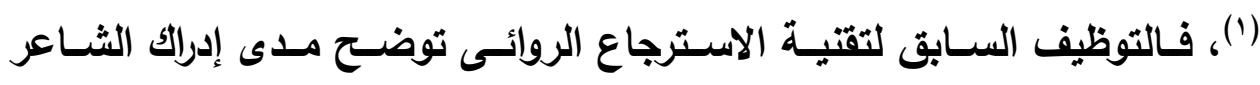

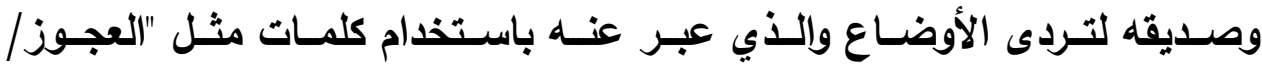

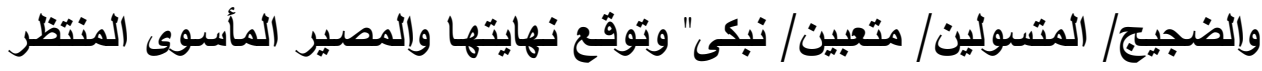

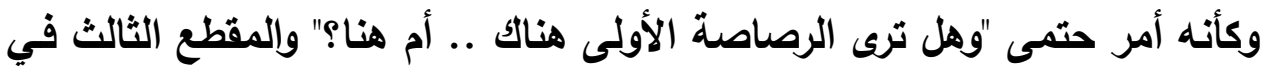

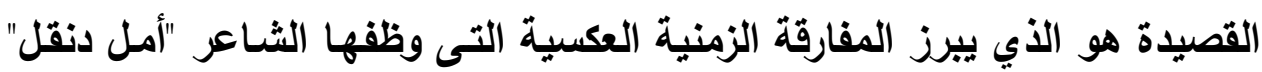

$=$ للمتلقى في العمل الروائى أو لسد بعض الفراغات في القص، وتأت تقتية الاستباق في العمل العال الروائسى أما عن طريق اقتراح بما سيحدث في المستقبل من قبل الرئل الراوي والطريقة الأخرى

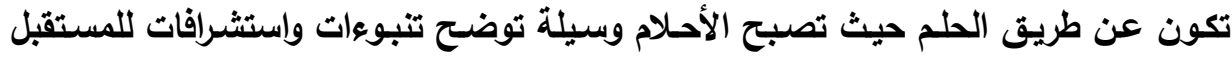

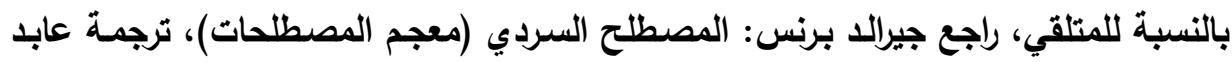

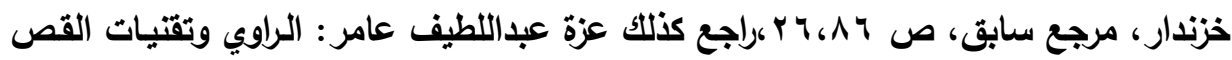

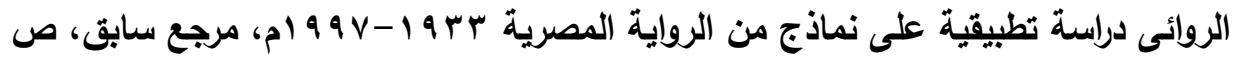

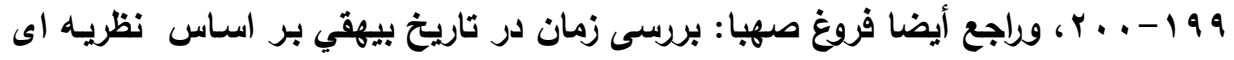

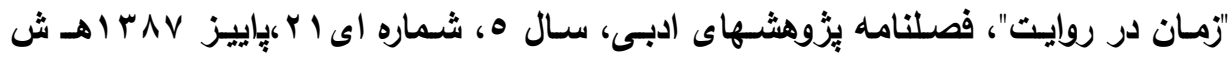

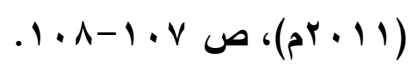

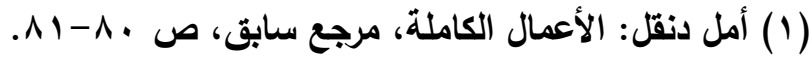


في بداية قصيدته حيث يقول: "الآن ها أنا/ أظل طول الليل لا يذوق جفنى وسنا/

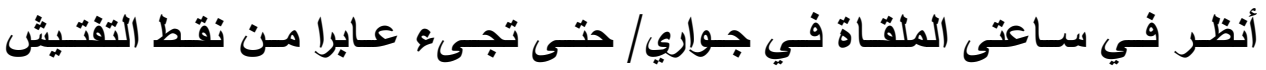

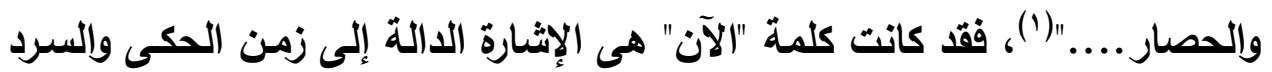

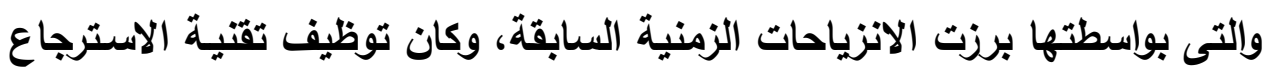

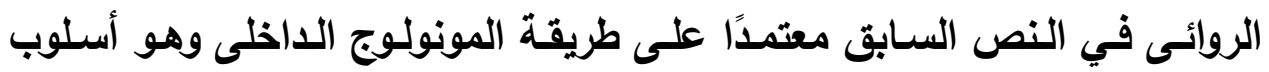

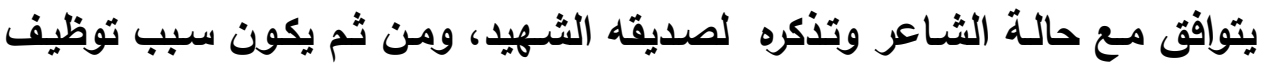
تقنية الاسترجاع الروائى في النص ترجع إلي ضرورة فنية لترابط الحبكة السردية

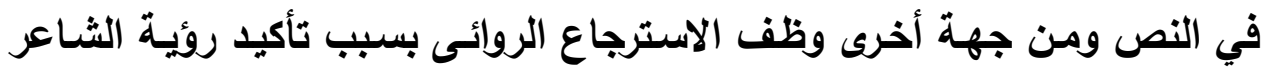
للحدث التاريخى والسياسي في النص.

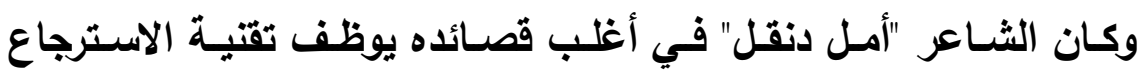

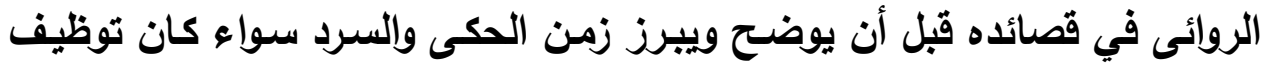

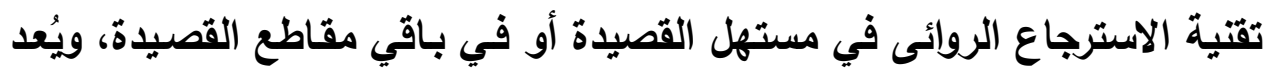

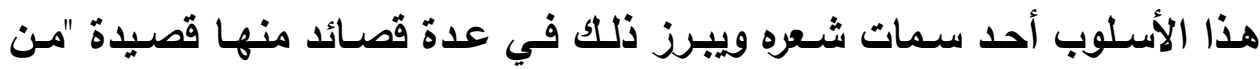

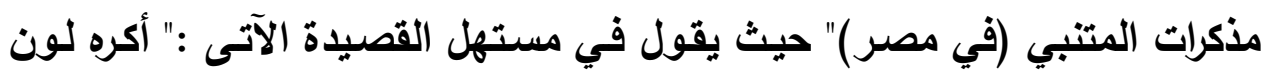

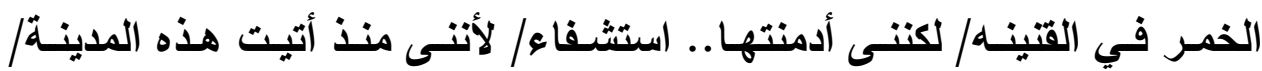

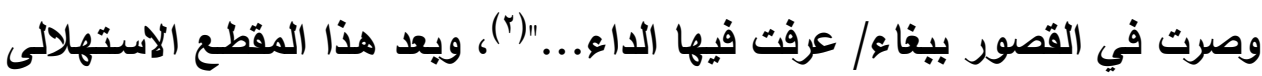
يبدأ الثاعر في سرد يومه بالتتابع الزمنى في قصر "كافور الأخشيدى" فيقول في لئي

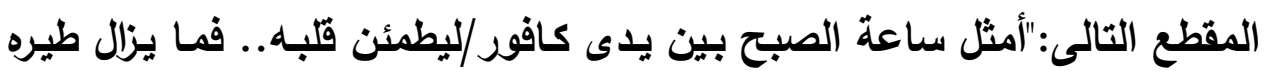

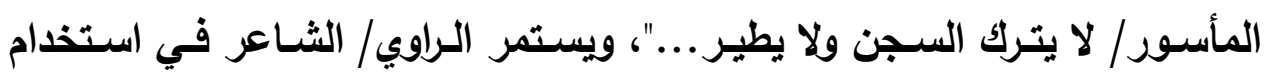
السرد حتى يقوم بتوظيف تقتية الاسترجاع الروائى مرة أخرى فيغير من زمن السرد لئرد

(1) أمل دنقل: الأعمال الكاملة، مرجع سابق، ص ا 1.

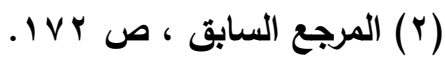




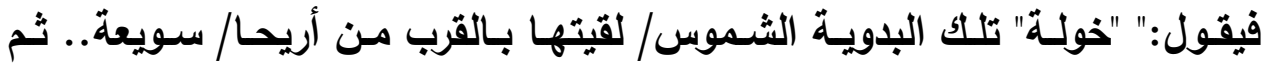

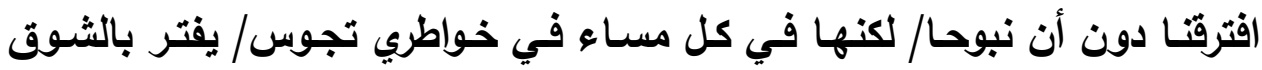
ويالعتاب ثغرها العبوس/ أشم وجهها الصبوحا/ أضم صدرها الجموحا/... ... ...

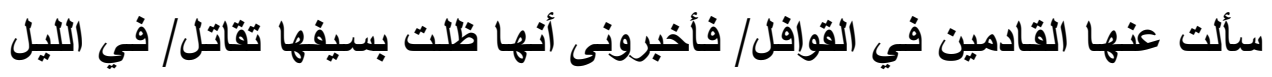

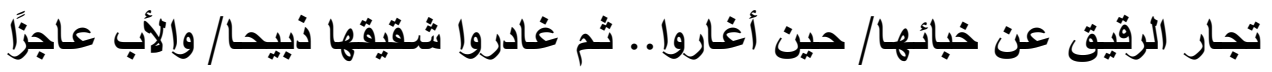

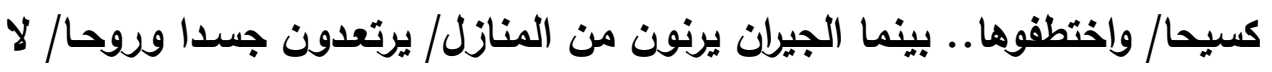

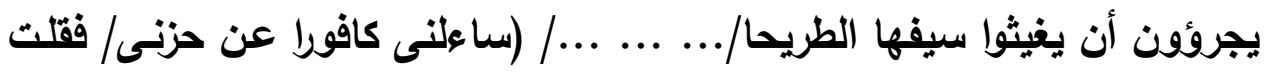

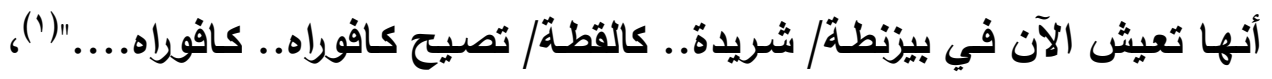
في المقطع السابق وظف الثاعر "أمل دنقل" تقنية الاسترجاع الروائى مرتين في لئي المرة الأولى "خولة" تلك البدوية الثموس/ لقيتها بالقرب من أريحا/ سويعة.. ثم

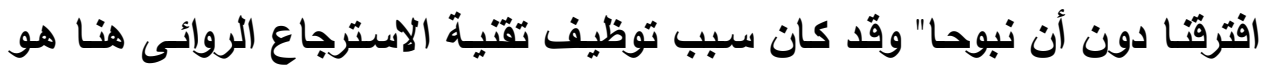

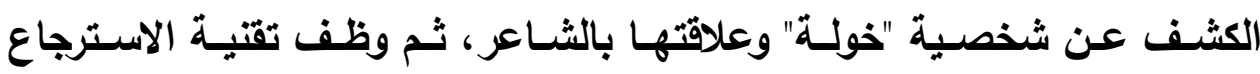

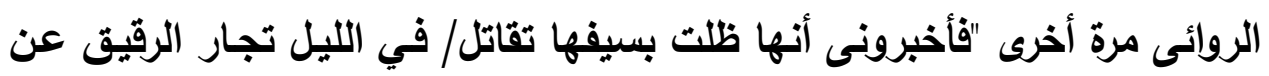

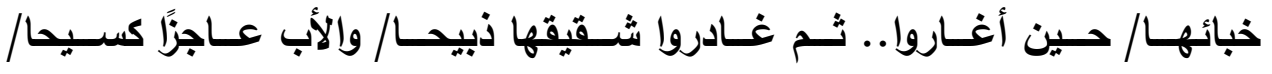

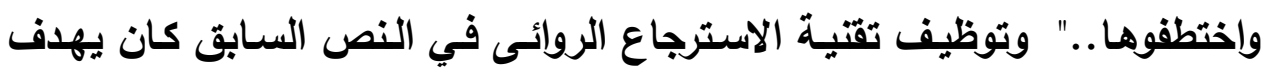

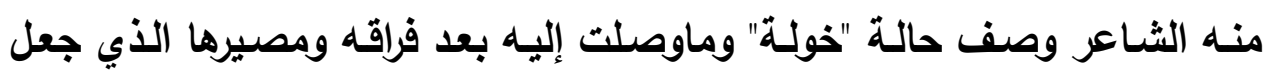

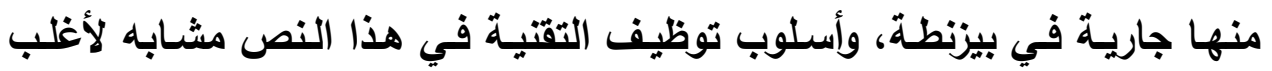

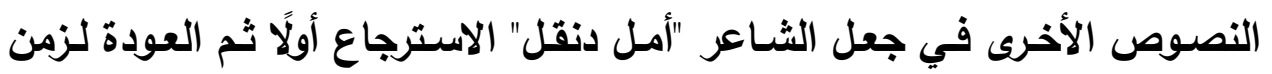

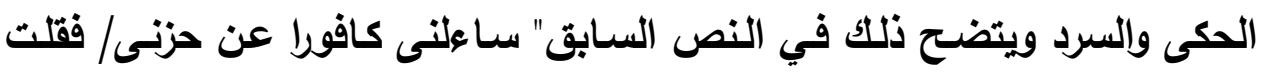

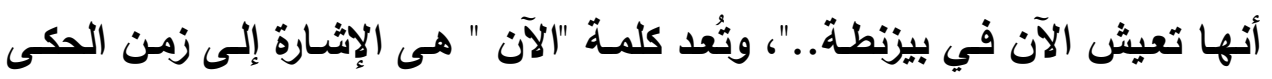

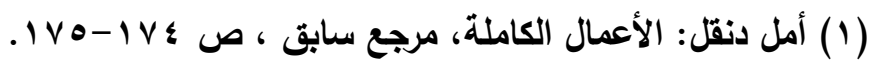


والسرد، والجدير بالذكر أن كلمـة "الآن" هـ أكثر كلمـة استخدمها الثـاعر "أمل دنقل" لتوضيح زمن الحكى والسرد.

ومن القصائد الأخرى التـى وظف من خلالها الثـاعر "أمل دنقل" تقنية الاسترجاع الروائى قصيدة "كلمات سبارتاكوس الأخيرة" حيث كان يهلف الثـاعر

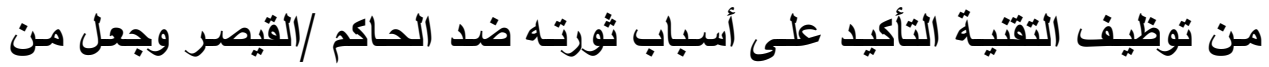

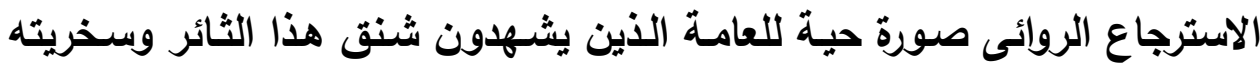

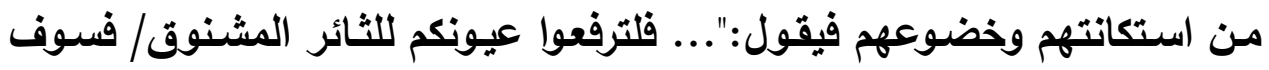

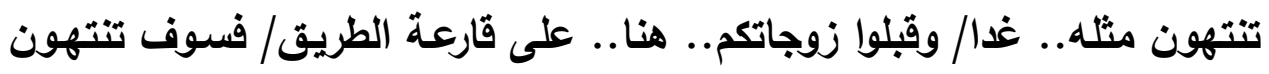

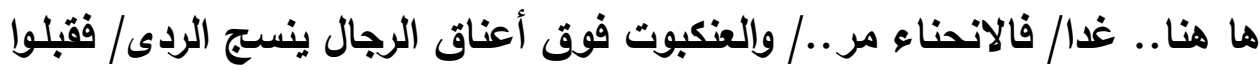

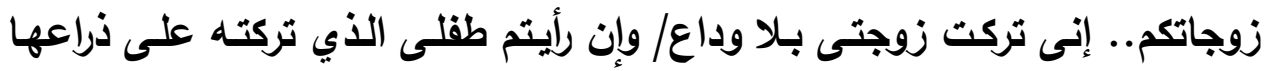

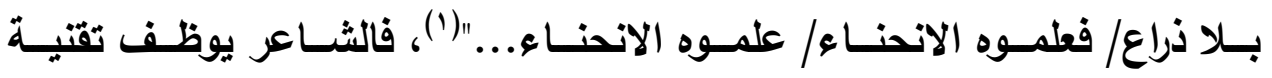

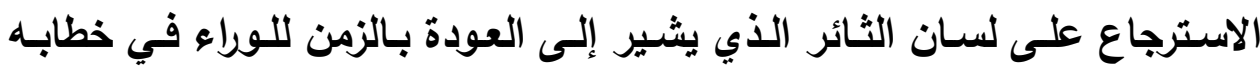
للعامة المارين أمام مشنقته ووصف لحظة رحيله حينما لم يودع زوجته أو يقبلها

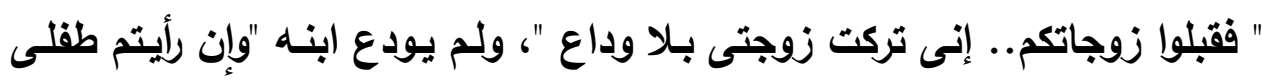

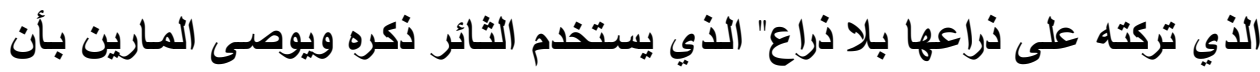

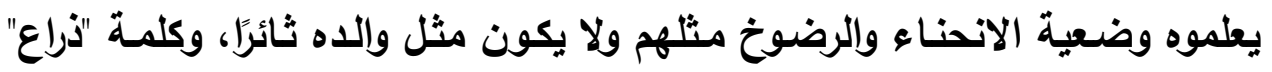

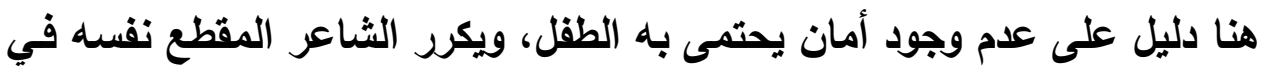

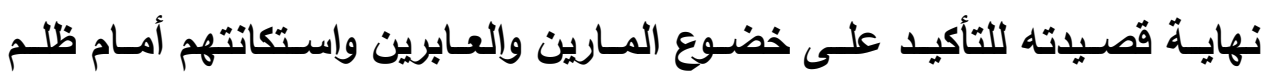

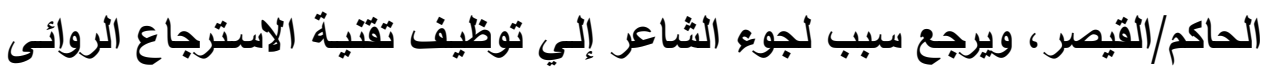

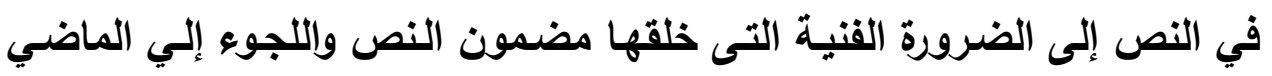

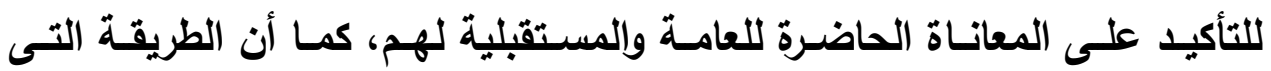

(1) أمل دنقل: الأعمال الكاملة، مرجع سابق، ص ع ^-هـ. 
استخدمها الثـاعر في توظيف تقتيـة الاسترجاع هـى المونولـوج الـاخلى التـى تتناسب مع الشخصية الراوي/ المشنوق.

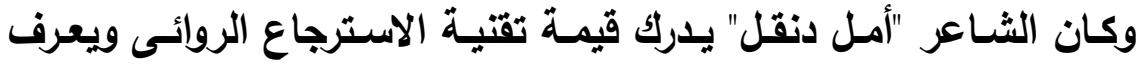

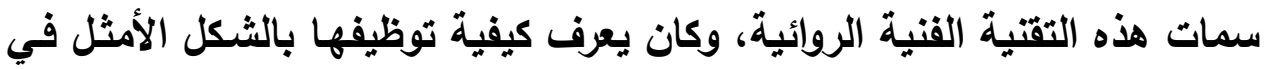

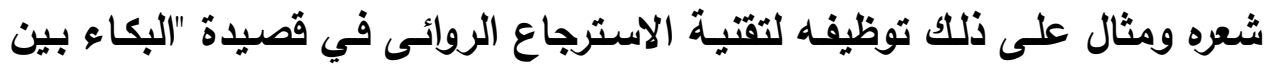

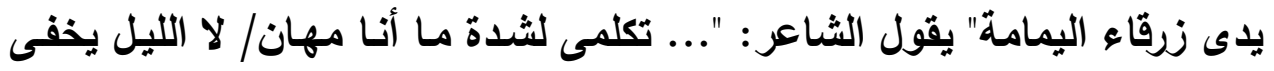

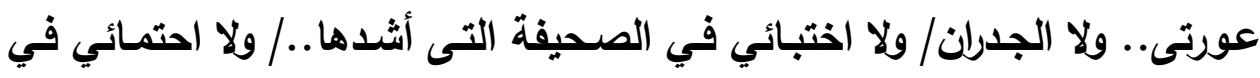

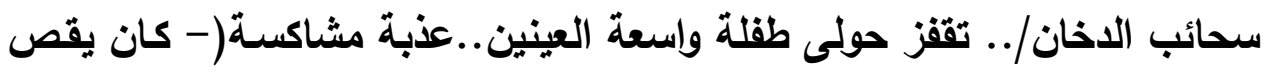

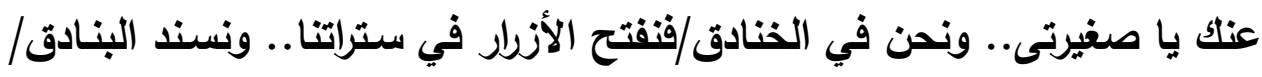

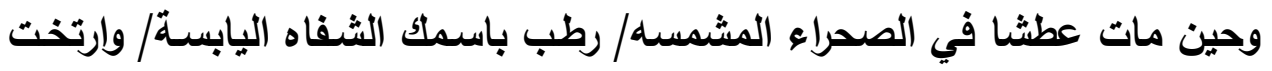

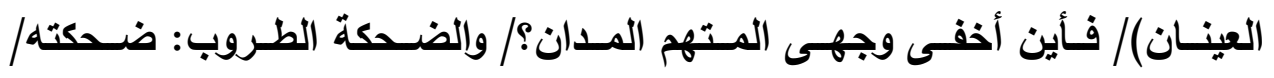

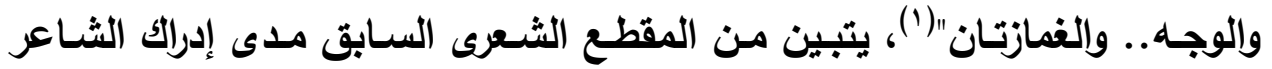
لتقتية الاسترجاع وتوظيفها بأن جعل السرد المسترجع في جبهـة القتـال لحسال

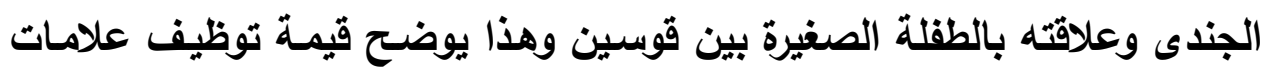

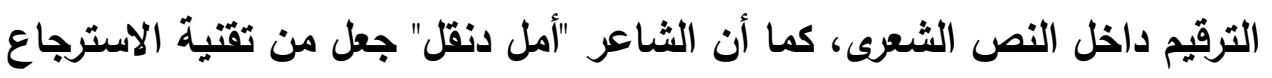

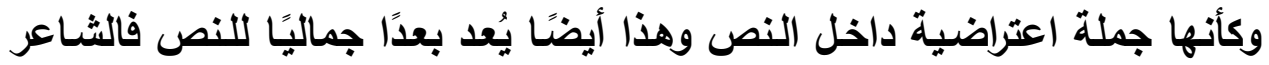

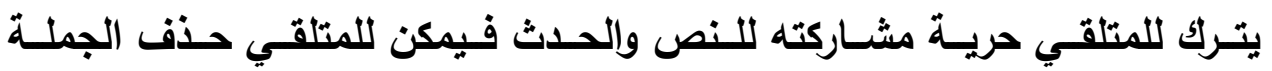
الاعتراضية والتى تمثل السرد المسترجع أو أن يكون هذا السرد المسترجع بالنسبة

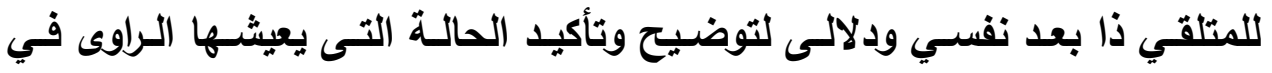

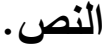

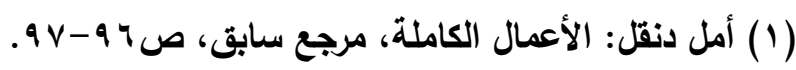


ويتبين مـن النمـاذج السـابقة أن تقنيـات الاسـترجاع الروائسى في ديـوان

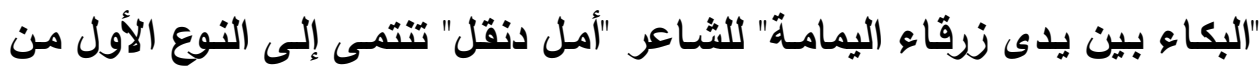

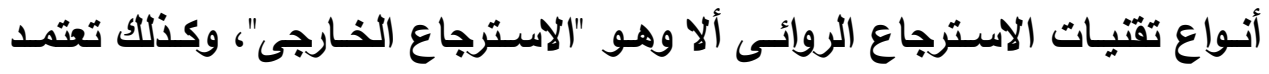

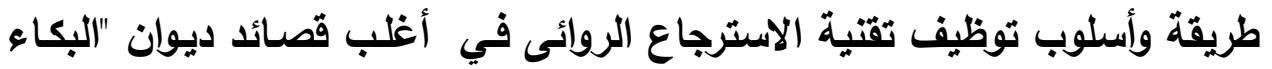
بين يدى زرقاء اليمامة" على فكرة تقديم الاسترجاع الروائى في مستهل القصيدة

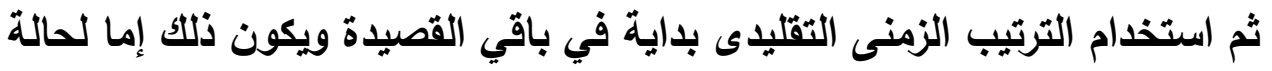
شعورية أو للكثف عن أبعاد الثخصيات داخل النص أو لضرورة فنية ويمكن توضيح ذلك من خلال الرسم التوضيحى الآتى:

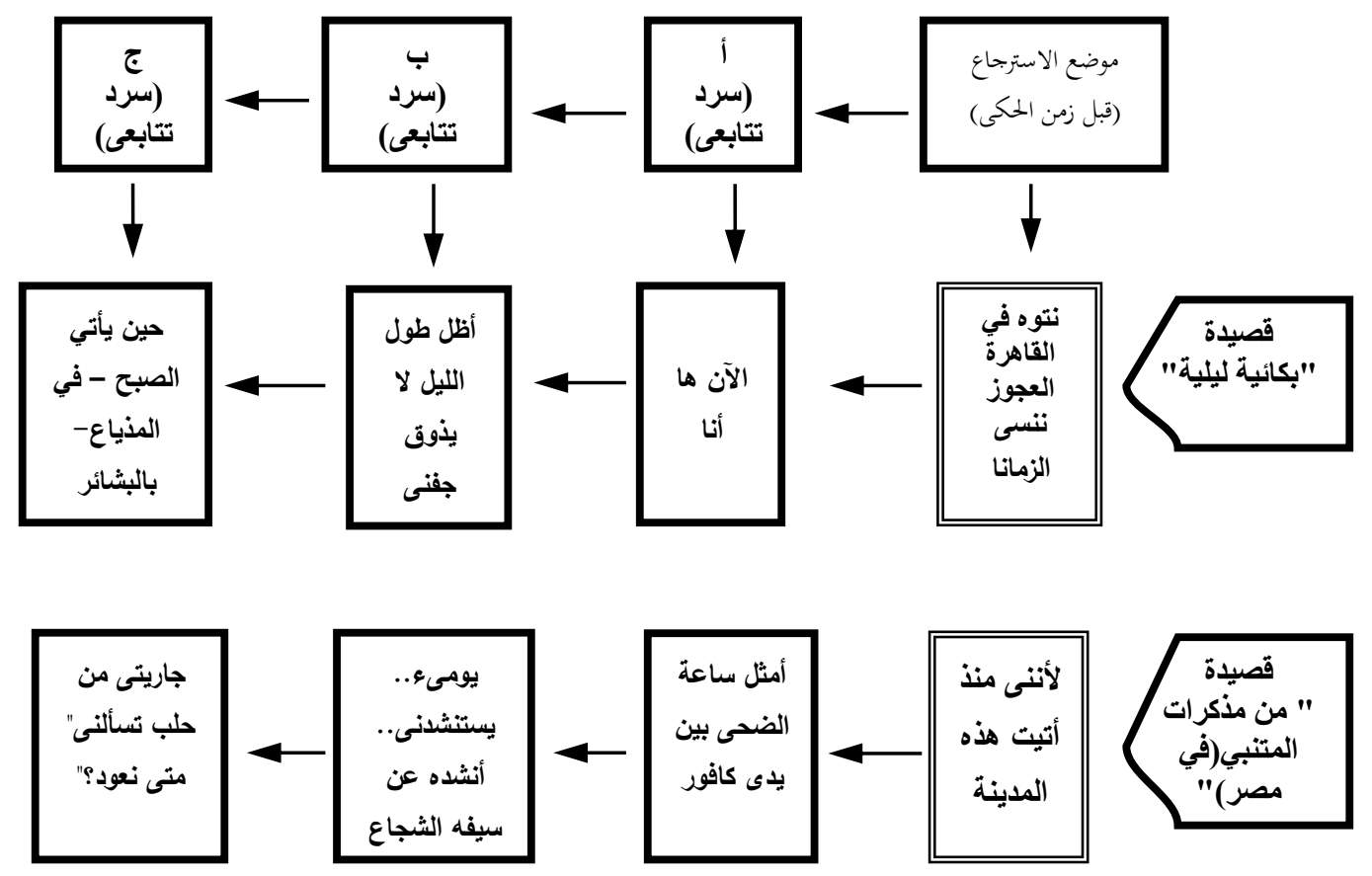


ومن سمات توظيف تقتية الاسترجاع الروائسى في ديوان الثـاعر "أمل

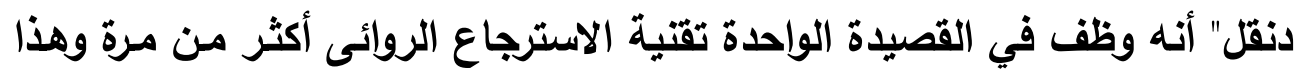

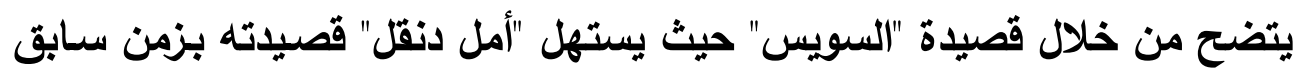

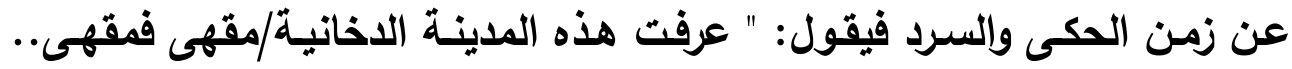

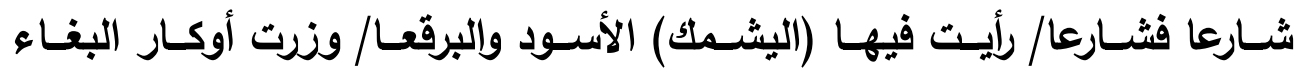

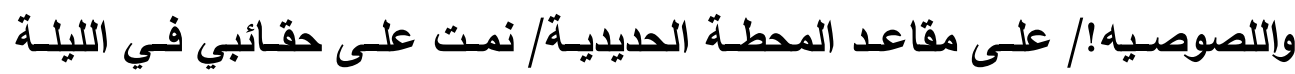

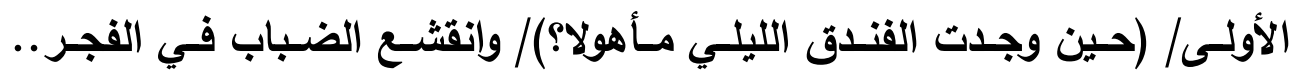
فكثف البيوت والمصانعا/ والسفن التى تسير في القتاة كـالإوز . / والصائدين العائدين في الزوارق البخارية!/ (رأيت عمال "السماد" يهبطون من قطار "المحجر"

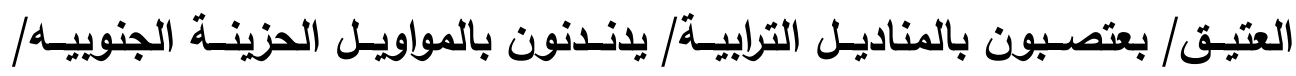

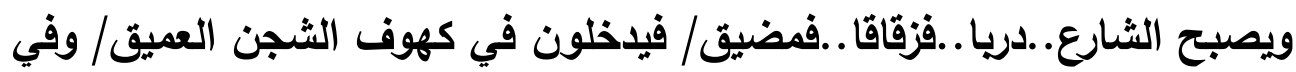

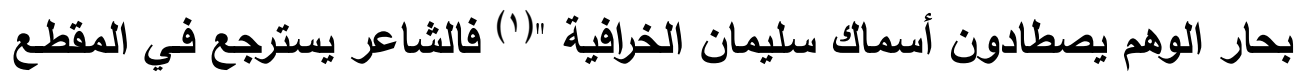

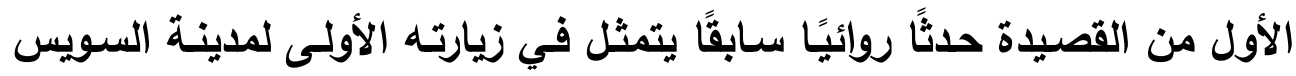

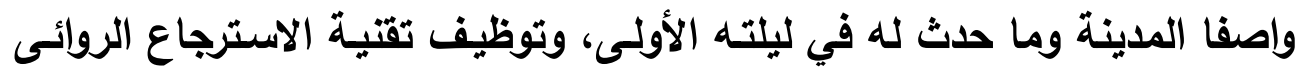
في مستهل القصيدة غرضـه هو الكثف عن وصف مدينـة السويس المحور

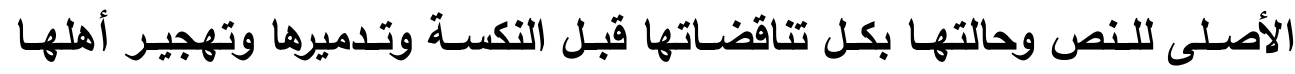
والكشف عن علاقة الراوي/الثاعر بالمدينة وأهلها والتى تؤدي إلى الكشف عن

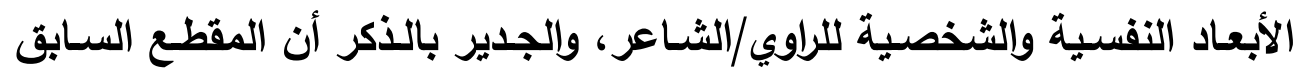

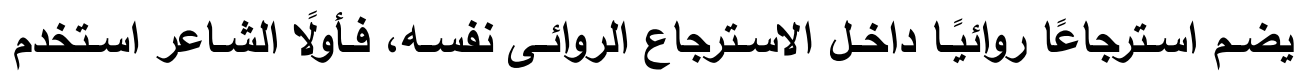

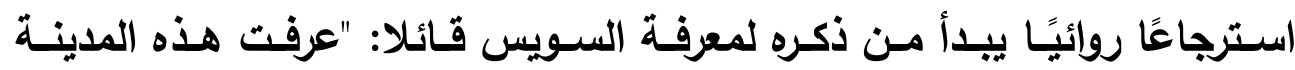

(1) أمل دنقل: الأعمال الكاملة، مرجع سابق، ص V • 1- ^ • 1. 
الاخانيـة..." ووصفه لمعرفته بهـا ومــا شـاهده وزاره في المدينـة ثم يستخدم

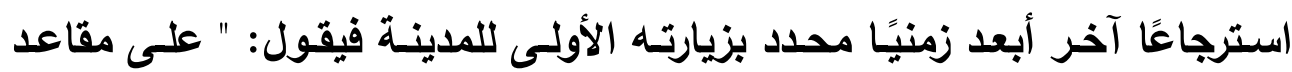
المحطة الحديدية/ نمت على حقائبي في الليلة الأولى/(حين وجلت الفيل الفندق الليلي

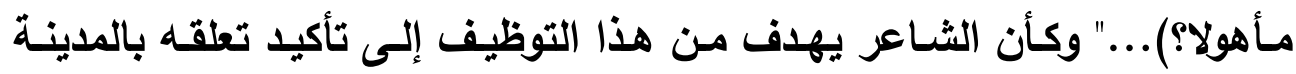
وتذكره لأدق التفاصيل ورصده ومشاهدته للمدينة. ويستمر الثاعر في المقطع الثانى في استخدام تقنية الاسترجاع الروائسى

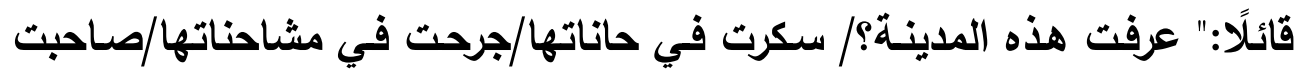

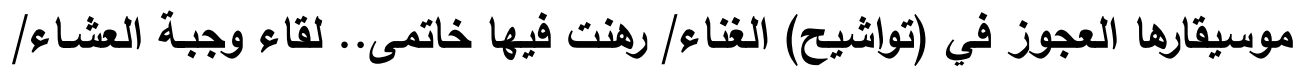

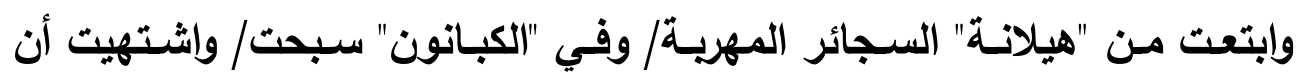

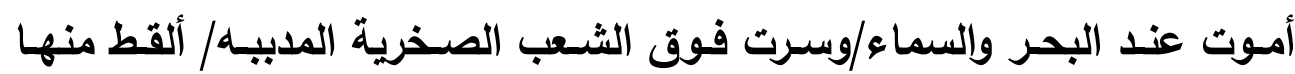

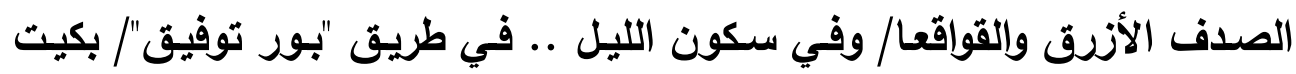

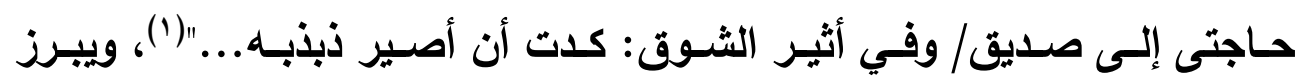

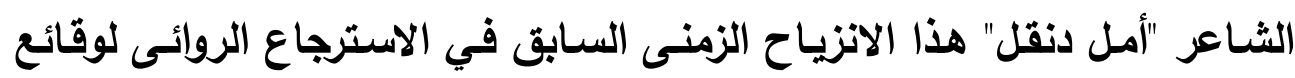

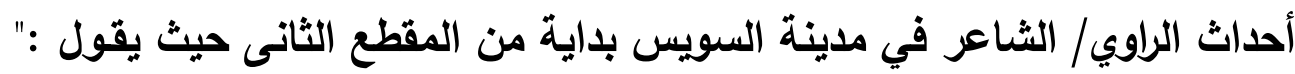

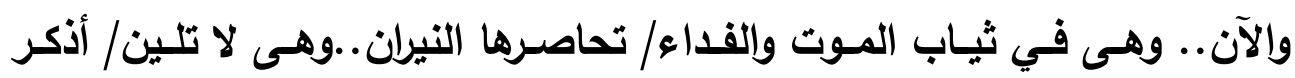

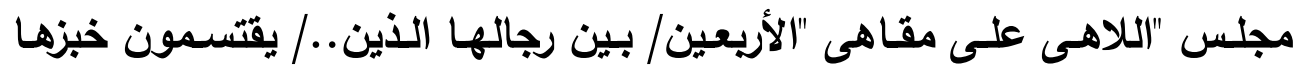

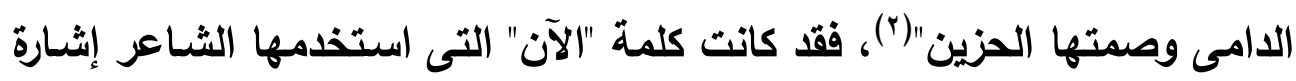
إلى زمن الحكى والسرد ويوظقها لتوقف الانزياحات الزمنية السابقة والتى خلقتها تقنية الاسترجاع الروائى، ويعد ذلك يوظف الثاعر تقنية الاسترجاع الروائسى مرة لتونه

(1) أمل دنقل: الأعمال الكاملة، مرجع سابق، ص 1 (1 1 - 9 ـ 1 .

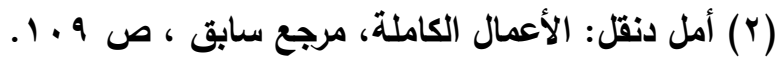


أخـرى باسـتخدام كلمـة " أذكر " ليـذكر أحداث النكسـة وتـدمير المدينـة ومقتـل

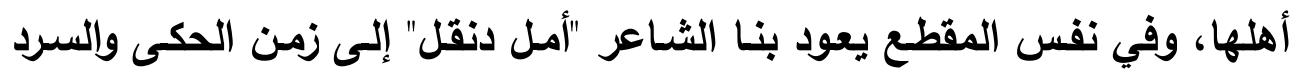

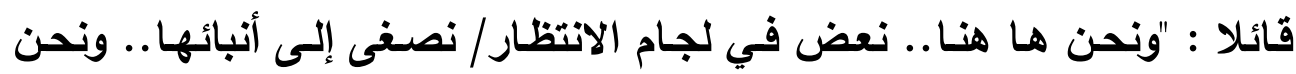

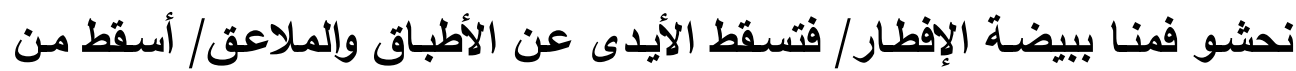

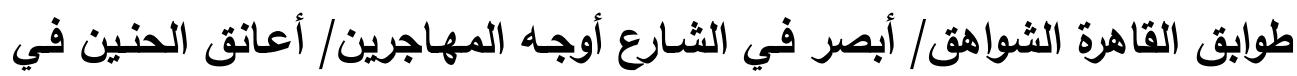

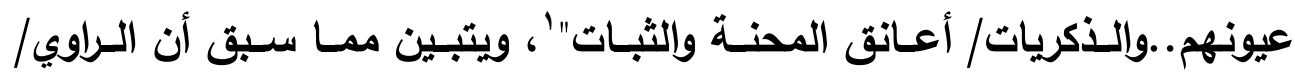

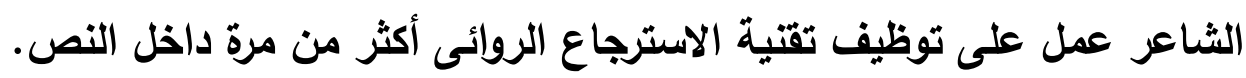




\section{الغاتمة}

لقد توصلت الاراسة بناء على ما سبق تتاولهه إلى عدد من النتائج يمكن

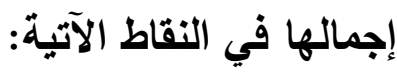

1- لجوء كل من الثـاعرة "فروغ فرخزاد" والثشاعر "أمل دنقل" إلى توظيف تقتيات

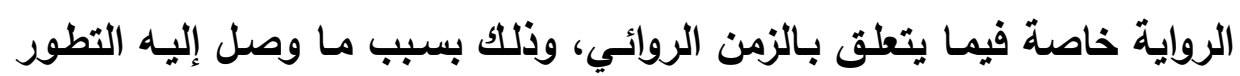
الثعرى فيما يتعلق ببنية النص وأدواته.

r- تعتمد طريقة وأسلوب توظيف تقتية الاسترجاع الروائى في أغلب قصائد ديوان

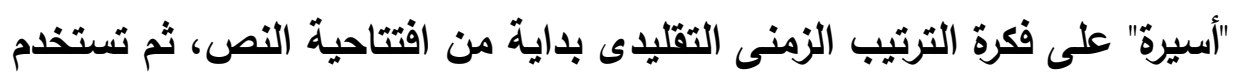

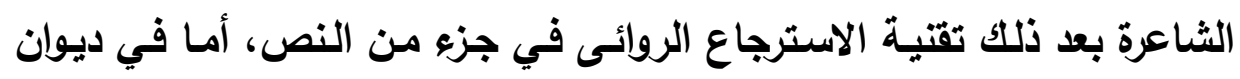

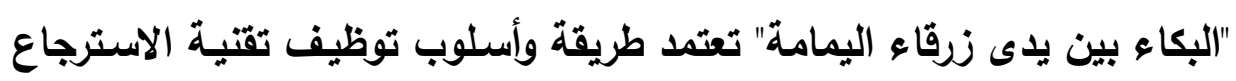

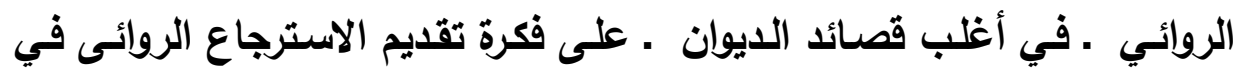
مستهل القصيدة ثم استخدام الترتيب الزمنى التقليدى بلاية في باقي القصيدة. r- تثثابهت أسباب توظيف تقتية الاسترجاع الروائسى في ديوان "أسيرة" وديوان

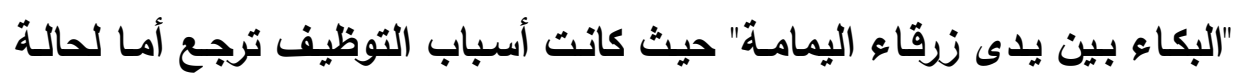

شعورية، أو للكثف عن أبعاد الثخصيات داخل النص، أو لضرورة فنية.

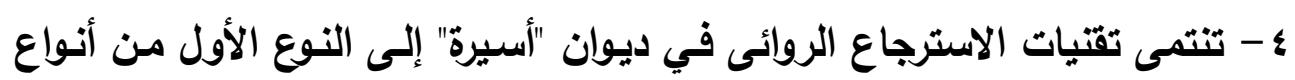

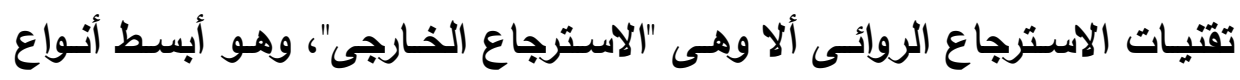

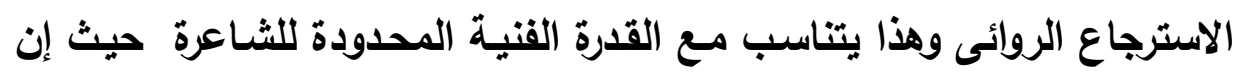

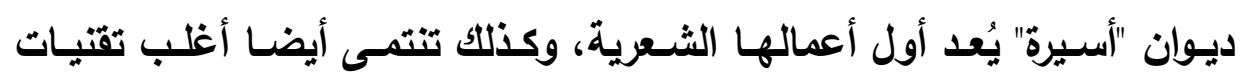

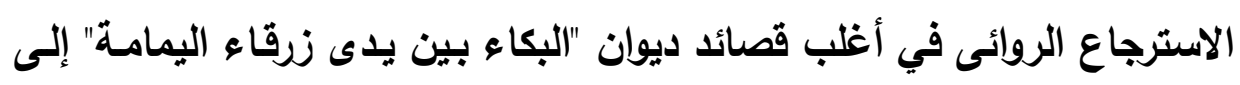

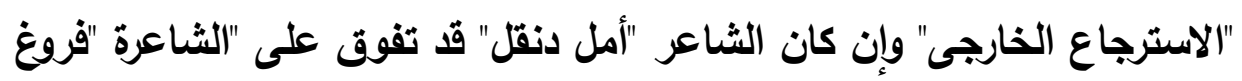


فرخزاد" في توظيفه - في بعض قصائد الديوان - للا"الاسترجاع المركب" وهو

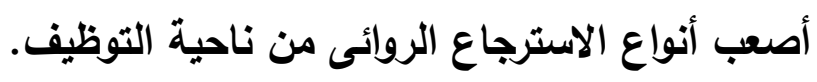

ه- كـان الثـاعر "أمـل دنقل" أكثر توظيفـا لتقنيـة الاسترجاع الروائسى في ديوانـهـ

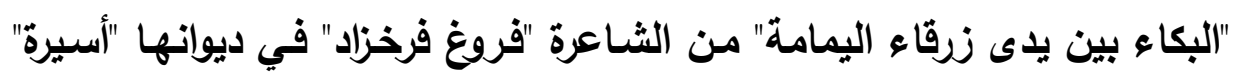

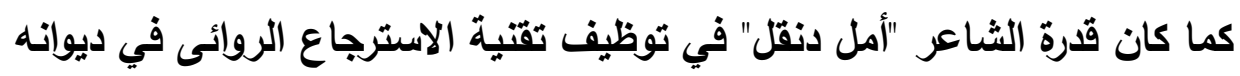

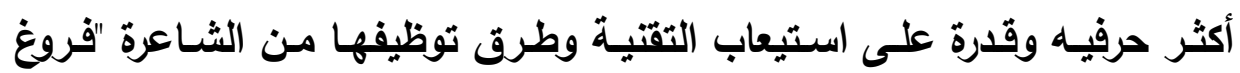

\section{فرخزاد" في ديوانها "أسيرة". \\ التوصيات والاستشراف:}

يُعد التاخل بين الأجناس الأدبية بعضها البعض من جهة ويبين الأجناس

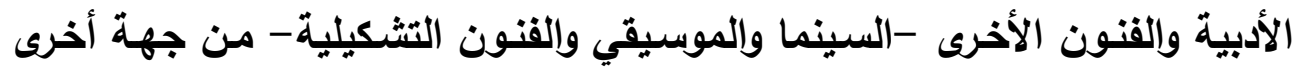

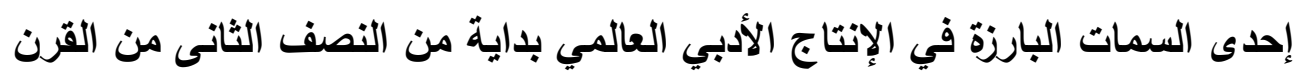

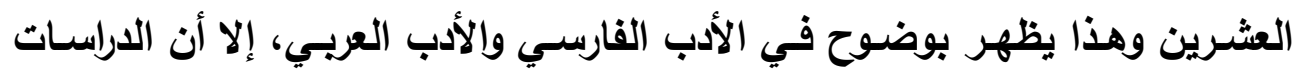

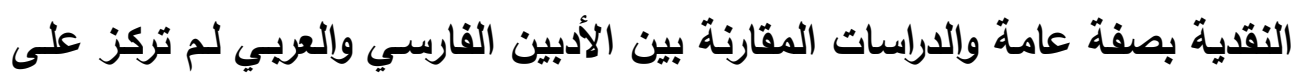

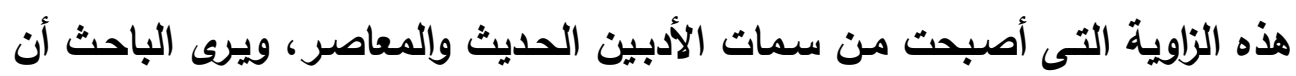

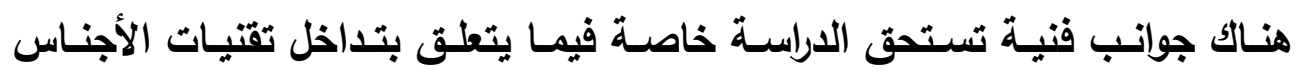

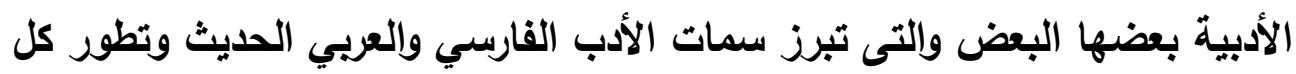

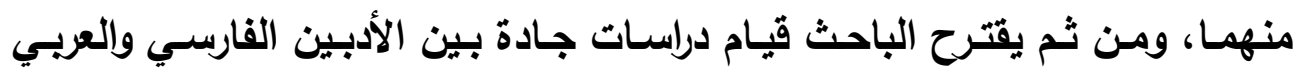

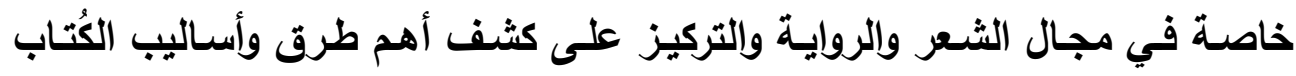

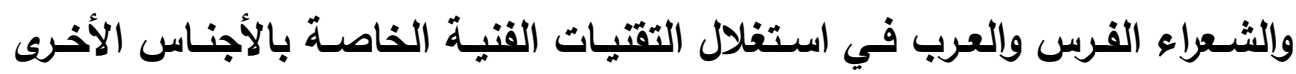
داخل أعمالهم ومدى قدرتهم على تطبيقها ومعرفة أسباب توظيف هذا التقنيات، وأثر ذلك التوظيف على سمات كل منهما. 


\section{قائمة المصادر والمراجع}

\section{أولا : المصادر والمراجع باللغة العربية والمترجمة إلى العربية:}

ا. إبـراهيم الاسـوقي شـتا: الثـعر الفارسـي الحـديث دراسـة ومختـارات، الطبعة الأولى، الهيئة المصرية العامة للكتاب، القاهرة، بم 9 ام.

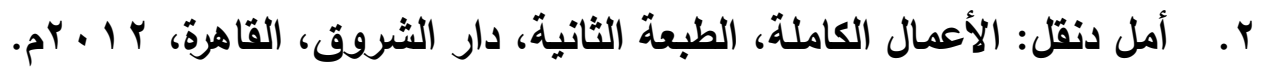

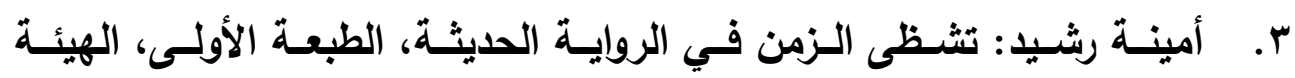

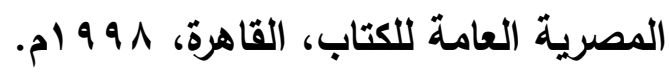
ع. بشري محمد على الخطيب: القصـة والحكايـة في الشـعر العريسي في صدر الإسلام والثعر الاموى، الطبعة الأولى، دار الثؤون الثقافية العامـة، العراق، . 199 . ه. جيـرار جنيـت خطـاب الحكايـة بحـث فـي المـنهج، ترجمـة محمــ معتصـم وآخـرون، الطبعـة الثانيـة، المشـروع القـومى للترجمـة - المجلس الأعلـي للثقافة، القاهرة، 99 أمرون 7 . جيرالد برنس: المصطلح السردي (معجم المصطلحات)، ترجمة عابد خزندار، الطبعة الأولى، المشروع القومى للترجمة- المجلس الأعلى للثقافة، القاهرة،

$$
\cdot p^{r} \cdot r
$$

V. سـيزا قاسـم: بنـاء الروايـة دراسـة مقارنـة في ثلاثبـة نجيب محفوظ، الطبعة

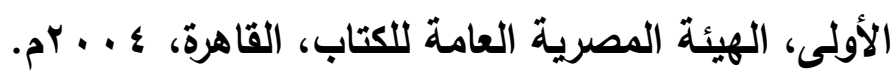
^. طـه وادي: جماليـات القصسيدة المعاصسرة، الطبعة الأولىى، الثـركة المصسرية

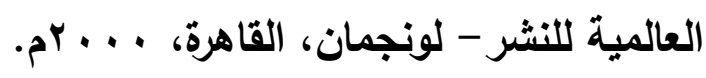


9 9. فروغ فرخزاد: مختـارات مسن أثـعار الشـاعرة الإيرانيـة فروغ فرخزاد، ترجمـة:

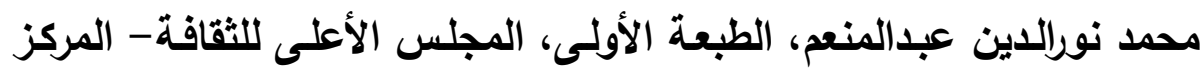

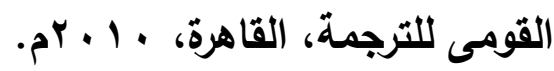

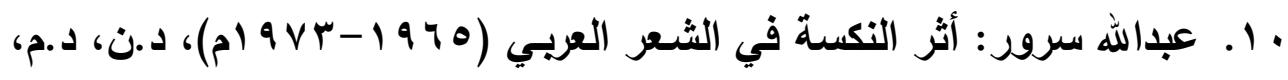
.01911 11 ـ . عبلة الروينى: الجنويي (سيرة أمل دنقل)، الطبعة الأولى، دار سعاد الصباح،

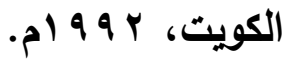
r 1. . عزة عبداللطيف عامر : الراوي وتقتيات القص الروائسى دراسـة تطبيقية على

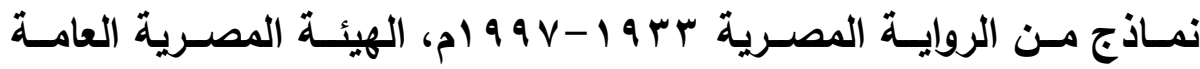

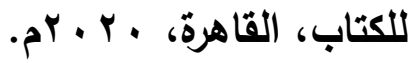
r ا. علي حوم: أدوات جديدة في التعبير الثعرى المعاصر، الطبعة الأولى، الهيئة

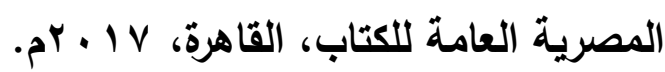
؛ 1 ـ محمـد السـعيد عبدالمؤمن: الروئية والنسـيج في الثـعر الإيرانسى المعاصر،

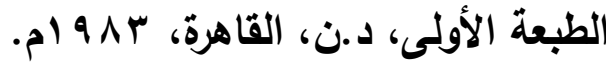

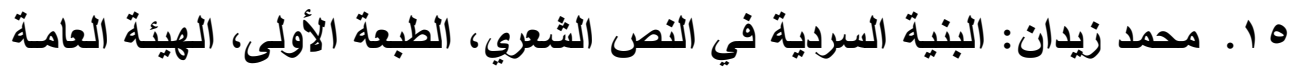

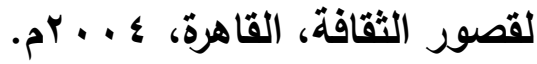
17 ـ نفيسة معتوق: البنية الزمنية في رواية "يوميات نائب في الأرياف" لـ"توفيق

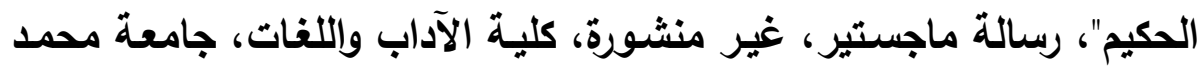

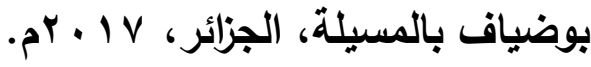




\section{ثانيا: الاصادر والمراجع بالاغة الفارسية والمترجمة إلى الفارسية:}

ا. افسانه محمدى: بررسس مكان وزمـان در رمـان "مرافىع الحب السبعة" اثر

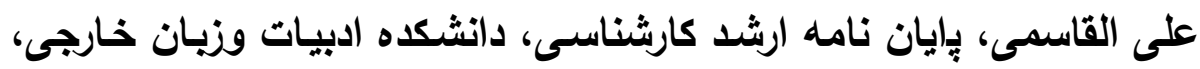

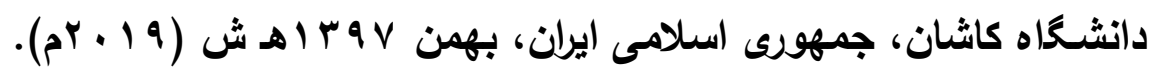

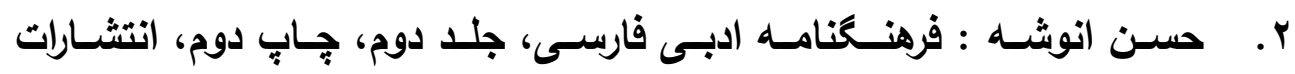

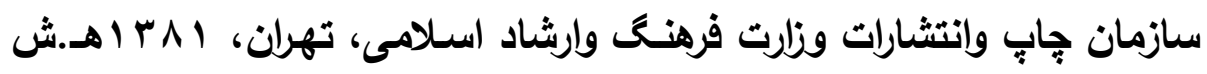

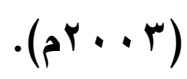

r. سـهيلا مباركى و زكيه رشيد آبادى: بررسى شكست زمـان ونابهنـامس در

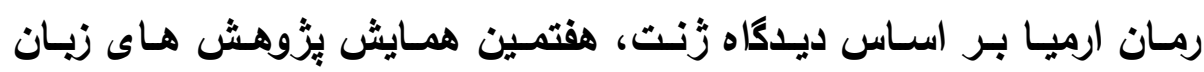

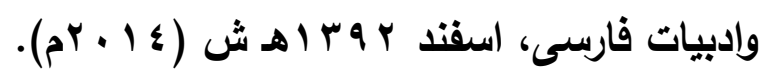

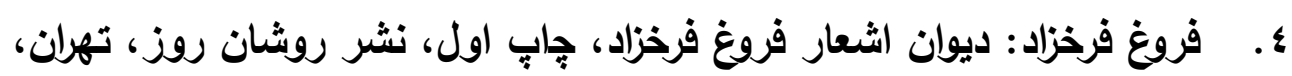

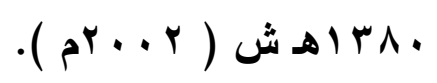

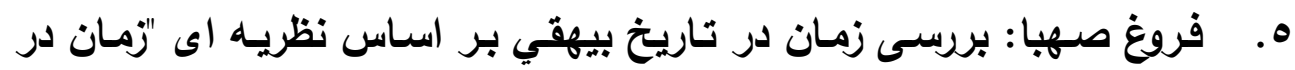

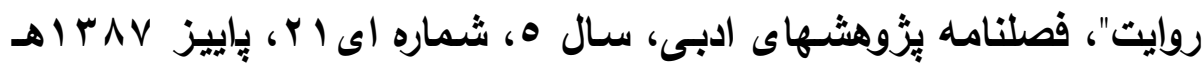

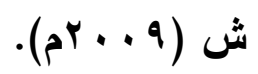

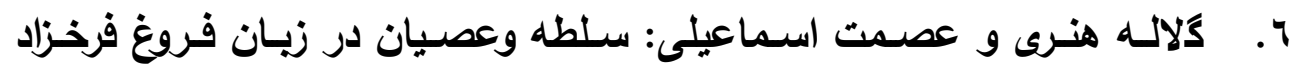

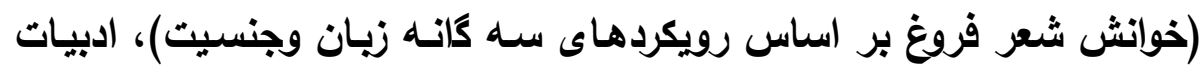

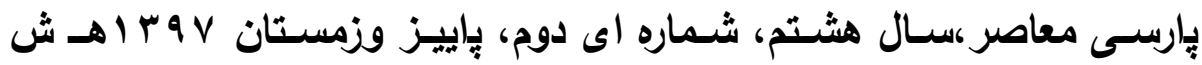

$$
\text { ( مجمد (19) }
$$

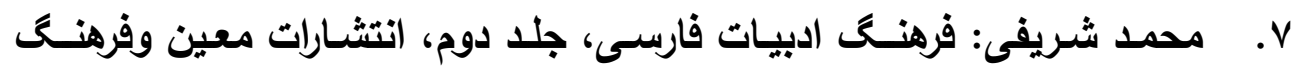

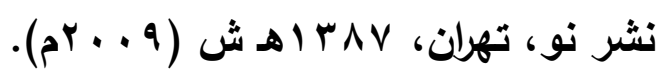




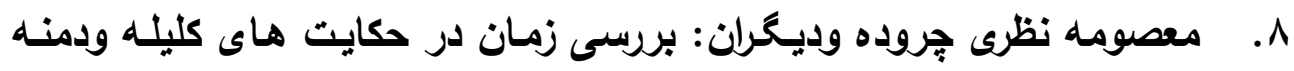

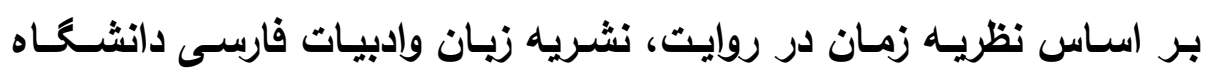

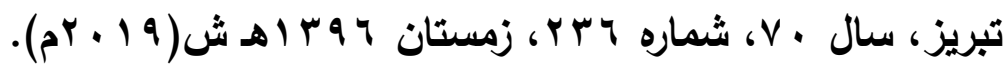

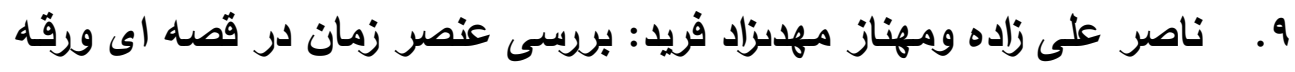

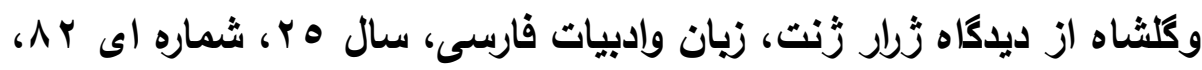

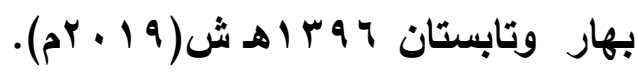

